\title{
40. PALEOMAGNETISM OF LEG 115 SEDIMENTS: IMPLICATIONS FOR NEOGENE MAGNETOSTRATIGRAPHY AND PALEOLATITUDE OF THE REUNION HOTSPOT ${ }^{1}$
}

\author{
David A. Schneider ${ }^{2}$ and Dennis V. Kent ${ }^{2}$
}

\begin{abstract}
Ocean Drilling Program Leg 115 was designed to study Neogene sedimentation history in the western Indian Ocean Basin as well as the Cenozoic evolution of the Réunion hotspot. We describe the paleomagnetic analysis of the sediments recovered on this leg, focusing on the sites that provided the most readily interpretable data: Sites 706, 709, 710, and 711. Sediments from Site 706 show no reversals but appear to give a reliable reversed polarity primary direction, judged on the basis of the demagnetization behavior of individual samples as well as from the results of a fold test formulated by comparing the two holes drilled at this site. Magnetic polarity stratigraphy in sediments from Site 709 can be deduced in two limited sections of Pliocene-Pleistocene and Oligocene-Miocene age. Sediments recovered at Site 710 (and, to a lesser extent, Site 711) render a relatively continuous magnetic polarity stratigraphy that spans most of the Neogene and adds significantly to the body of data available to address problems in Miocene geochronology.

In addition to these magnetostratigraphic results, the paleomagnetism of these sediments can be used to determine paleolatitude. Using the most reliable inclination measurements from Sites 706, 710, and 711, we compared paleomagnetic estimates of paleolatitude with estimates derived from a hotspot-based absolute plate motion model. Our data, which covers the interval since $33 \mathrm{Ma}$, shows that paleolatitudes calculated with the geocentric axial dipole assumption are in general accord with the hotspot predictions. However, a correction for the long-term nondipole field brings the paleomagnetic results into even better agreement with plate motions that are based on the fixity of African hotspots.
\end{abstract}

\section{INTRODUCTION}

Ocean Drilling Program (ODP) Leg 115 in the western equatorial Indian Ocean was designed to address two distinct themes: (1) Neogene sedimentation and dissolution history in the basin, and (2) the Cenozoic evolution of the Réunion hotspot. A study of the paleomagnetism of the sediments recovered on Leg 115 contributes centrally to these scientific objectives. In this report, we show that magnetic polarity stratigraphy, used in conjunction with biostratigraphy, provides detailed age control for much of the sedimentary column obtained at several sites. This precision in dating directly serves the paleoceanographic objectives of Leg 115, allowing the variation in sedimentation and dissolution to be followed in greater detail. Furthermore, we show that inclination measurements obtained from the sediments can supplement the paleomagnetic data gathered from the basement rocks and thus help to fulfill the tectonic objective of documenting any latitudinal motion of the Réunion hotspot.

The paleomagnetic data presented below are of two fundamentally different types: those obtained using the shipboard pass-through magnetometer (PTM) and those derived from conventional analysis of discrete sediment samples. The PTM system provides an economical means to obtain a high density of measurements and gives a near-continuous record of the sediment column; however, this measurement system was prone to special difficulties and limitations, as discussed below. The measurement of discrete samples supplements the higher resolution PTM data obtained on board the ship and acts as a valuable calibration of the PTM results.

Two general limitations governed the emphasis of our work with Leg 115 sediments. First, at the generally low latitudes that the sites occupied, polarity reversals could be reliably detected only in those sediments not rotated during drilling, that is,

\footnotetext{
${ }^{1}$ Duncan, R. A., Backman, J., Peterson, L. C., et al., 1990. Proc. ODP, Sci. Results, 115: College Station, TX (Ocean Drilling Program).

2 Lamont-Doherty Geological Observatory and Department of Geological Sciences, Columbia University, Palisades, NY 10964, U.S.A.
}

those recovered by hydraulic piston coring. Thus, virtually all of the data presented here are from cores taken using the advanced hydraulic piston corer (APC).

Ideally, the use of an orientation tool should allow such APC cores to be oriented in azimuth; however, the orientation device did not function reliably during this leg. Consequently, declination measurements could be used to identify reversals within a core, but could not establish the sense of the magnetic polarity changes. Thus, in each core polarity sense had to be determined from what are, at low latitudes, more subtle changes in paleomagnetic inclination. Also, we observed that even in the apparently undisturbed sediments recovered with the APC, remagnetization during coring was not only common but could be quite severe. A full description of this remagnetization process is given elsewhere (Backman, Duncan, et al., 1988, pp. 475-476); however, the effect is discussed briefly below to help interpret the combined results of PTM and discrete sample measurements.

In this paper, each of the sites occupied on Leg 115 (Fig. 1) are discussed in turn, with the more closely associated sites (Sites 705/706 and Sites 712/713) considered together. The four sites that provided the most satisfactory paleomagnetic results are considered in greatest detail; these are Sites 706, 709, 710, and 711. Sediments from Site 706 recorded no polarity reversals, but the inclination measurements from these sediments provide a well-constrained paleolatitude estimate for this site, the southernmost point on the Réunion hotspot trace sampled during Leg 115. The results from Site 709 were, in general, of poor quality; however, the magnetostratigraphy of some Pliocene and lower Miocene/upper Oligocene intervals was determined. The paleomagnetic study of sediments from Sites 710 and 711 proved most successful, with the Neogene-age sections from these two sites providing a largely continuous magnetic polarity stratigraphy.

\section{METHODS}

Shipboard PTM measurements were routinely taken on archival core sections before and after alternating-field demagnetization. The demagnetization field used was typically $5 \mathrm{mT}$. On 




Figure 1. Generalized tectonic map of the Indian Ocean region showing the location of Leg 115 sites (after Backman, Duncan, et al., 1988).

occasion, the maximum working field of the pass-through demagnetizer $(9 \mathrm{mT})$ was attempted; however, shipboard experiments indicated that an anhysteretic remanent magnetization (ARM) could be imparted at the higher demagnetization levels; thus, a 5-mT field was routinely adopted. Discrete samples were taken by pressing $6-\mathrm{cm}^{3}$ plastic sample boxes into the working half of the cores. Typically, these were sampled at $1.5-\mathrm{m}$ intervals (one sample per core section). Most discrete samples examined were subjected to progressive alternating-field (AF) demagnetization; however, in some instances blanket AF treatment was applied after a pilot subset of the samples was analyzed with progressive treatment to determine a suitable demagnetization level.

As mentioned, attempts were made during coring to orient the cores in azimuth using the Eastman-Whipstock photographic orientation device; however, the procedures used on Leg 115 proved to be unreliable. Thus, unless otherwise stated, the reported declination values are measured with respect to the fiducial markings on the core liners $\left(0^{\circ}\right.$ corresponds to the direction of the double fiducial line on the work half of the cores). Although the orientation device did not serve to orient the cores in azimuth, it was capable of measuring the drift (i.e., the deviation from vertical) of the hole being drilled. These drift measurements indicate that the cores generally penetrated the sediment at angles that were typically within $2^{\circ}$ of vertical (Table 1 ).

Of great concern in studying the paleomagnetism of these sediments is that a remagnetization, imparted by coring, is com- monly encountered. From various observations made on board (Backman, Duncan, et al., 1988, pp. 475-476), we concluded that the remanent magnetic field of a steel coring barrel could be imparted on the sediments contained within it. This possibly occurs as a core is raised within the drill string and is subjected to repeated shock and vibration. This remagnetization most severely affected the external portions of the cores (presumably because the outside of the core is physically closer to the magnetized core barrel); thus, PTM results generally show a more intense remagnetization than do discrete sample measurements.

After identifying the source of this remagnetization on board, attempts were made to reduce the remanent field of the core barrels using a MAGNAFLUX apparatus as a crude AF demagnetizer. These efforts, however, were only partially successful. In general, inclination measurements from the PTM appear to be affected severely by remagnetization induced by the core barrels, although declination shows field reversals more reliably. A typical example of this behavior is shown in Figure 2. We suspect that our attempts to demagnetize the core barrels acted to align their magnetization axially, but did not eliminate their remanent field. Hence, we base our interpretations largely on declination measurements, which are shown in the summary magnetostratigraphic figures.

Another potentially misleading effect commonly arises in which the PTM appears to record a short polarity interval of some $10-20 \mathrm{~cm}$ width where none actually exists. This phenomenon occurs when the intrinsic magnetization varies substan- 
Table 1. Results from Eastman-Whipstock photographic orientation tool.

\begin{tabular}{|c|c|c|c|c|}
\hline Core & $\begin{array}{c}\text { Drift } \\
\text { amount }\end{array}$ & $\begin{array}{c}\text { Drift } \\
\text { direction }\end{array}$ & $\begin{array}{l}\text { Declination } \\
\text { of fiducial }\end{array}$ & $\begin{array}{c}\text { Instrument } \\
\text { number }\end{array}$ \\
\hline \multicolumn{5}{|l|}{$115-707 \mathrm{~A}-$} \\
\hline $4 \mathrm{H}$ & 2.0 & - & 80 & 1711 \\
\hline $5 \mathrm{H}$ & 2.5 & - & 310 & 1711 \\
\hline $6 \mathrm{H}$ & 2.3 & - & 295 & 40649 \\
\hline $7 \mathrm{H}$ & 1.8 & - & 127 & 40649 \\
\hline $8 \mathrm{H}$ & 1.8 & 225 & 135 & 1711 \\
\hline $9 \mathrm{H}$ & 1.8 & 115 & 249 & 1711 \\
\hline $10 \mathrm{H}$ & 1.6 & 112 & 250 & 1711 \\
\hline $11 \mathrm{H}$ & 1.9 & 290 & 220 & 40649 \\
\hline $12 \mathrm{H}$ & 2.0 & 34 & 235 & 40649 \\
\hline $13 \mathrm{H}$ & 1.9 & 273 & 215 & 40649 \\
\hline $14 \mathrm{H}$ & 1.7 & 100 & 225 & 1711 \\
\hline $15 \mathrm{H}$ & 1.5 & 150 & 45 & 1711 \\
\hline $16 \mathrm{H}$ & 1.5 & 185 & 230 & 1711 \\
\hline $17 \mathrm{H}$ & 1.2 & 257 & 205 & 40649 \\
\hline $18 \mathrm{H}$ & 1.1 & 168 & 234 & 40649 \\
\hline $19 \mathrm{H}$ & 1.5 & 215 & 328 & 40649 \\
\hline \multicolumn{5}{|l|}{$115-708 \mathrm{~A}-$} \\
\hline $4 \mathrm{H}$ & 0.5 & 90 & 98 & 1606 \\
\hline SH & 2.0 & 140 & 292 & 1606 \\
\hline $6 \mathrm{H}$ & 1.0 & 120 & 284 & 1711 \\
\hline $7 \mathrm{H}$ & 0.9 & 105 & 249 & 1711 \\
\hline $8 \mathrm{H}$ & 0.5 & 65 & 124 & 1606 \\
\hline \multicolumn{5}{|l|}{$115-709 \mathrm{~A}-$} \\
\hline $4 \mathrm{H}$ & 0.5 & 220 & 130 & 1606 \\
\hline $5 \mathrm{H}$ & 1.0 & 220 & 335 & 1606 \\
\hline $6 \mathrm{H}$ & 0.7 & 270 & 335 & 1606 \\
\hline $7 \mathrm{H}$ & 1.0 & 240 & 90 & 1711 \\
\hline $8 \mathrm{H}$ & 0.9 & - & - & 1711 \\
\hline $9 \mathrm{H}$ & 1.0 & - & - & 1711 \\
\hline $10 \mathrm{H}$ & 0.5 & 280 & 28 & 1606 \\
\hline $11 \mathrm{H}$ & 0.5 & 280 & 20 & 1606 \\
\hline $12 \mathrm{H}$ & 0.5 & 270 & 20 & 1606 \\
\hline $13 \mathrm{H}$ & 0.6 & 70 & 59 & 1711 \\
\hline $14 \mathrm{H}$ & 0.5 & 60 & 324 & 1711 \\
\hline $15 \mathrm{H}$ & 0.9 & 40 & 125 & 1711 \\
\hline $16 \mathrm{H}$ & 0.5 & 45 & 82 & 1606 \\
\hline $17 \mathrm{H}$ & 0.5 & 95 & 358 & 1606 \\
\hline
\end{tabular}

tially over a short distance, for example, when measuring a thin high-carbonate (low magnetization) turbidite that lies within more clay-rich (high magnetization) layers. If the scale of variation is comparable with the width of the response function of the magnetometer (roughly $20 \mathrm{~cm}$ ), the magnetization direction may seemingly reverse. This happens as the signal becomes dominated by higher magnetization material contributing to the negative flanks of the magnetometer response function. This effect is most obvious around gaps in the cores where large samples were removed before splitting for geochemical analysis (Fig. 3 ). We have carefully scrutinized the intensity record of all short polarity zones indicated by the PTM in an effort to separate true short polarity zones from this common artifact. We consider those in which the intensity remains relatively low within the entire interval to be suspect; those in which the intensity clearly recovers from bounding intensity lows, we take to record genuine short polarity intervals.

Because of the severe effects of the remagnetization on PTM measurement of inclination, polarity assignment within any given core is often difficult to determine. However, for the large majority of the cores in which reversals were detected, polarity sense can be confidently assigned by examining the inclination of discrete samples or by using only the least contaminated portion of the PTM inclination record. Only in a few cases is the polarity assignment unclear, and these instances are noted explicitly in our description of results.
Table 1 (Continued).

\begin{tabular}{|c|c|c|c|c|}
\hline Core & $\begin{array}{c}\text { Drift } \\
\text { amount }\end{array}$ & $\begin{array}{c}\text { Drift } \\
\text { direction }\end{array}$ & $\begin{array}{l}\text { Declination } \\
\text { of fiducial }\end{array}$ & $\begin{array}{l}\text { Instrument } \\
\text { number }\end{array}$ \\
\hline \multicolumn{5}{|c|}{ 115-709A- (cont.) } \\
\hline $18 \mathrm{H}$ & 0.8 & 85 & 238 & 1606 \\
\hline $19 \mathrm{H}$ & 1.0 & 100 & 150 & 1711 \\
\hline $20 \mathrm{H}$ & 0.9 & 105 & 153 & 1711 \\
\hline $21 \mathrm{H}$ & 0.5 & 50 & 85 & 1711 \\
\hline \multicolumn{5}{|l|}{ 115-709B- } \\
\hline $4 \mathrm{H}$ & 0.1 & 80 & 170 & 1711 \\
\hline $5 \mathrm{H}$ & 0.3 & 200 & 292 & 1711 \\
\hline $6 \mathrm{H}$ & 0.1 & 170 & 242 & 1711 \\
\hline $7 \mathrm{H}$ & 0.5 & 230 & 343 & 1606 \\
\hline $8 \mathrm{H}$ & 0.5 & 270 & 75 & 1606 \\
\hline $9 \mathrm{H}$ & 0.5 & 170 & 275 & 1606 \\
\hline $14 \mathrm{H}$ & 0.5 & 250 & 345 & 1711 \\
\hline $15 \mathrm{H}$ & 0.5 & 290 & 95 & 1711 \\
\hline $16 \mathrm{H}$ & 0.5 & 295 & 110 & 1711 \\
\hline $17 \mathrm{H}$ & 0.5 & 195 & 312 & 1606 \\
\hline $18 \mathrm{H}$ & 0.8 & 215 & 15 & 1606 \\
\hline $19 \mathrm{H}$ & 0.5 & 250 & 54 & 1606 \\
\hline \multicolumn{5}{|l|}{$115-710 \mathrm{~A}-$} \\
\hline $4 \mathrm{H}$ & 1.6 & 285 & 225 & 1711 \\
\hline $5 \mathrm{H}$ & 1.6 & 290 & 233 & 1711 \\
\hline $6 \mathrm{H}$ & 1.7 & 293 & 298 & 1711 \\
\hline $7 \mathrm{H}$ & 1.9 & 286 & 344 & 1711 \\
\hline $8 \mathrm{H}$ & 2.0 & 290 & 92 & 1606 \\
\hline $9 \mathrm{H}$ & 1.8 & 270 & 10 & 1606 \\
\hline $10 \mathrm{H}$ & 1.8 & 315 & 179 & 1606 \\
\hline $11 \mathrm{H}$ & 1.0 & 300 & 244 & 1606 \\
\hline $12 \mathrm{H}$ & 1.3 & 304 & 70 & 1711 \\
\hline $13 \mathrm{H}$ & 1.5 & 275 & 92 & 1711 \\
\hline \multicolumn{5}{|l|}{$115-711 \mathrm{~A}-$} \\
\hline $4 \mathrm{H}$ & 4.3 & 110 & 180 & 1606 \\
\hline $5 \mathrm{H}$ & 4.5 & 110 & 136 & 1606 \\
\hline $6 \mathrm{H}$ & 4.3 & 110 & 13 & 1606 \\
\hline $7 \mathrm{H}$ & 4.0 & 110 & 234 & 1606 \\
\hline $8 \mathrm{H}$ & 4.0 & 110 & 240 & 40649 \\
\hline $9 \mathrm{H}$ & 3.8 & 110 & 190 & 40649 \\
\hline $10 \mathrm{H}$ & 3.5 & 110 & 187 & 40649 \\
\hline $11 \mathrm{H}$ & 3.0 & 100 & 35 & 40649 \\
\hline
\end{tabular}

Because the core barrel remagnetization most affects PTM measurements, we derive numerical estimates of inclination only from discrete samples. Because the relative orientation in azimuth between cores is unknown, Fisher statistics (Fisher, 1953) cannot be applied; instead, we average the inclination values obtained from each of the discrete samples using a maximum likelihood technique (McFadden and Reid, 1982), which gives an estimate of mean inclination and the Fisher precision parameter, kappa $(\kappa)$. (Note that in performing this correction, we take care to use McFadden and Reid's equation 40 with the unhatted value of $\theta$ and not the hatted value as was incorrectly used in their numerical example, and so the maximum likelihood estimates of inclination are always steeper than the simple arithmetic average.) Using this estimate of $k$ with the number of samples averaged, we can compute an $\alpha_{95}$ estimate. Error limits on paleolatitude are determined by multiplying the calculated $\alpha_{95}$ value by 0.8 , so as not to overestimate the one-dimensional $95 \%$ confidence limits (Demarest, 1983).

As with all applications of magnetostratigraphy, correlation of polarity zones with the geomagnetic polarity time scale (GPTS) must be formulated in conjunction with the analysis of all independent age constraints available, in this case mostly biostratigraphic data. We used the chronology of Berggren et al. (1985a, 1985 b) as a foundation (Fig. 4), correlating magnetozones with the magnetic polarity time scale in the manner that appears most consistent with both the magnetics and the biostratigra- 


\section{Declination}


Figure 2. Typical paleomagnetic stratigraphy (this example is from Core 115-711A-3H), as determined by PTM after 5-mT demagnetization. Note that declination shifts appear to record reversals reliably despite the lack of corresponding sign changes in the inclination. This behavior most probably reflects the contamination of a vertical overprint caused by the core barrel.

phy. We do, however, recognize that portions of this global magnetobiostratigraphic time scale remain uncertain and that some of the detailed correlations may well not apply rigidly within the Indian Basin (Backman et al., this volume).

In naming the various polarity intervals, we use the familiar proper names for the Pliocene-Pleistocene magnetic chrons (Brunhes, Matuyama, Gauss, and Gilbert) and subchrons (e.g., Jara- millo and Olduvai). In referring to older intervals, we use the correlative magnetic anomaly number prefixed with the letter "C" (following the general scheme described by LaBrecque et al., 1983). We refer to normal zones with the suffix "N," reverse with "R." In referring to the various subchrons included in the time scale of Berggren et al. (1985a, 1985b), we use a numerical suffix that increases from youngest to oldest. Reversal bounda- 

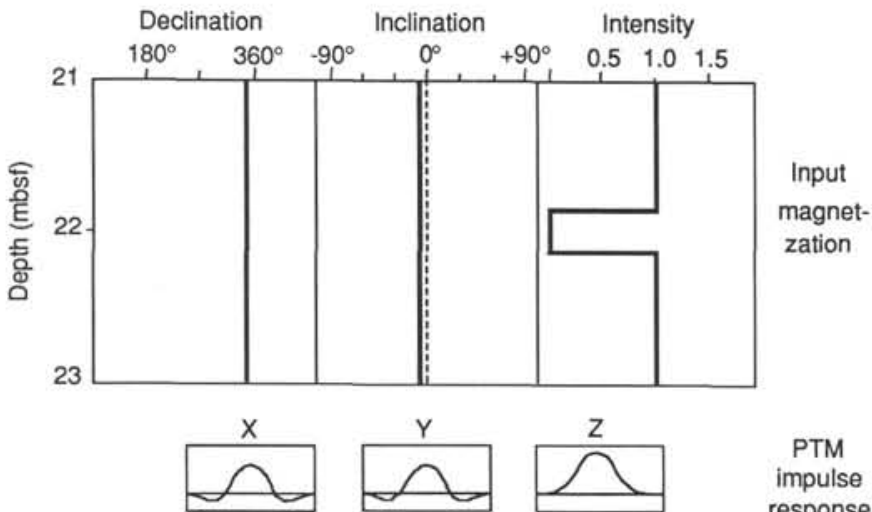

impulse response

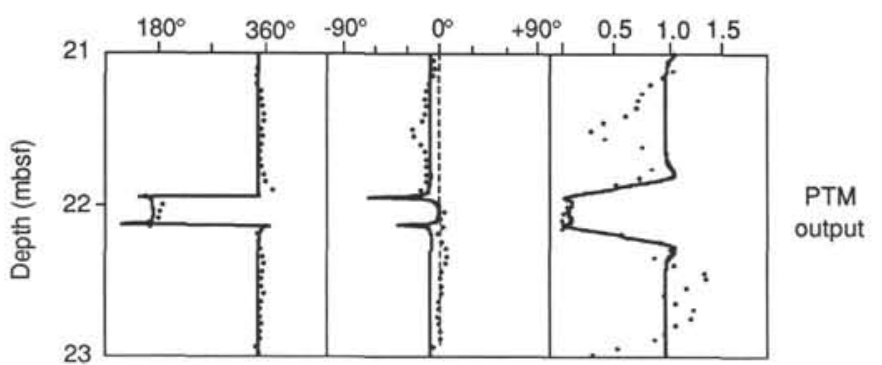

Figure 3. Pass-through magnetometer (PTM) response to a narrow interval of low intensity that gives rise to an apparent reversal of polarity. Solid lines in lower panels indicate calculated magnetometer output for a gap within a region of uniform magnetization. The configuration modeled very closely matches the observed magnetometer output (discrete points) from Core $115-710 \mathrm{~A}-3 \mathrm{H}$ where a $25-\mathrm{cm}$ section had been removed for geochemical analysis.

ries are denoted by the chron/subchron designation followed parenthetically by the letters " $\mathrm{O}$ " or "T," signifying onset or termination of the particular interval.

Note that in plotting the summary magnetostratigraphic figures we have rotated the declinations in each of the cores to bring the average declination of the normal polarity zones to $0^{\circ}$ (the rotations used for plotting are given in Table 2). The results of shore-based measurement of discrete samples shown in these figures are tabulated for Sites 706, 709, 710, and 711. The results of shipboard PTM measurements are not included as these data are available on request from the ODP.

\section{RESULTS}

\section{Sites 705 and 706}

The first hole drilled on Leg 115 at Site 705 was abandoned because the hole became unstable, and the ship was relocated to a more favorable site nearby. Site 706 is situated at $13^{\circ} 7^{\prime} \mathrm{S}$, $61^{\circ} 22^{\prime} \mathrm{E}$, at approximately $2500 \mathrm{~m}$ water depth, within a canyon incised in the northeastern shoulder of the Nazareth Bank. Other than the topmost few meters of sediment (which are composed of a coarse-grained Pleistocene foraminifer sand), this section consists of some $40 \mathrm{~m}$ of Oligocene nannofossil ooze overlying basement thought to be formed by the Réunion hotspot at $33 \mathrm{Ma}$ (Duncan and Hargraves, this volume).

The PTM measurements of these sediments revealed no strong evidence for reversals. Progressive demagnetization of discrete samples taken from this site typically indicates one or two components of magnetization (Fig. 5). When present, the low-coercivity component generally shows a steep downward direction and can be readily removed using demagnetizing fields of 5-10 $\mathrm{mT}$. The high-coercivity component is also directed downward



Figure 4. Geomagnetic polarity time scale (Berggren et al., 1985a, 1985 b) used in this study. Also shown are the age intervals for which a magnetostratigraphic record is available from Leg 115 sites. 
Table 2. Declination adjustments used in plotting summary magnetostratigraphic figures.

\begin{tabular}{|c|c|c|c|}
\hline Core & $\begin{array}{l}\text { Rotation } \\
\text { (degrees) }\end{array}$ & Core & $\begin{array}{l}\text { Rotation } \\
\text { (degrees) }\end{array}$ \\
\hline $115-709 \mathrm{~A}-1 \mathrm{H}$ & $70^{\circ}$ & 115-710B-5H & $240^{\circ}$ \\
\hline $115-709 \mathrm{~A}-2 \mathrm{H}$ & $*$ & $115-710 \mathrm{~B}-6 \mathrm{H}$ & $75^{\circ}$ \\
\hline $115-709 \mathrm{~A}-3 \mathrm{H}$ & $85^{\circ}$ & $115-710 \mathrm{~B}-7 \mathrm{H}$ & $160^{\circ}$ \\
\hline $115-709 \mathrm{~A}-4 \mathrm{H}$ & $90^{\circ}$ & $115-710 \mathrm{~B}-9 \mathrm{H}$ & $325^{\circ}$ \\
\hline $115-709 \mathrm{~A}-20 \mathrm{H}$ & $90^{\circ}$ & $115-711 \mathrm{~A}-1 \mathrm{H}$ & $290^{\circ}$ \\
\hline $115-709 \mathrm{~A}-21 \mathrm{H}$ & $270^{\circ}$ & $115-711 \mathrm{~A}-2 \mathrm{H}$ & $180^{\circ}$ \\
\hline 115-709B-1H & $270^{\circ}$ & $115-711 \mathrm{~A}-3 \mathrm{H}$ & $250^{\circ}$ \\
\hline $115-709 \mathrm{~B}-2 \mathrm{H}$ & * & $115-711 \mathrm{~A}-4 \mathrm{H}$ & $330^{\circ}$ \\
\hline $115-709 \mathrm{~B}-3 \mathrm{H}$ & $10^{\circ}$ & $115-711 \mathrm{~A}-5 \mathrm{H}$ & * \\
\hline $115-709 \mathrm{~B}-4 \mathrm{H}$ & $300^{\circ}$ & $115-711 \mathrm{~A}-6 \mathrm{H}$ & * \\
\hline $115-709 \mathrm{C}-19 \mathrm{H}$ & $80^{\circ}$ & $115-711 \mathrm{~A}-7 \mathrm{H}$ & * \\
\hline $115-710 \mathrm{~A}-1 \mathrm{H}$ & $180^{\circ}$ & $115-711 \mathrm{~A}-8 \mathrm{H}$ & * \\
\hline $115-710 \mathrm{~A}-2 \mathrm{H}$ & $290^{\circ}$ & $115-711 \mathrm{~A}-9 \mathrm{H}$ & $0^{\circ}$ \\
\hline $115-710 \mathrm{~A}-3 \mathrm{H}$ & $10^{\circ}$ & $115-711 \mathrm{~A}-10 \mathrm{H}$ & $0^{\circ}$ \\
\hline 115-710A-4H & $285^{\circ}$ & $115-711 \mathrm{~A}-11 \mathrm{H}$ & $250^{\circ}$ \\
\hline 115-710A-6H & $280^{\circ}$ & $115-711 \mathrm{~B}-1 \mathrm{H}$ & $315^{\circ}$ \\
\hline $115-710 \mathrm{~A}-7 \mathrm{H}$ & $150^{\circ}$ & $115-711 \mathrm{~B}-2 \mathrm{H}$ & $190^{\circ}$ \\
\hline $115-710 \mathrm{~A}-8 \mathrm{H}$ & $180^{\circ}$ & $115-711 \mathrm{~B}-3 \mathrm{H}$ & $330^{\circ}$ \\
\hline 115-710A-9H & $270^{\circ}$ & $115-711 \mathrm{~B}-4 \mathrm{H}$ & $270^{\circ}$ \\
\hline $115-710 \mathrm{~A}-10 \mathrm{H}$ & 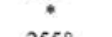 & 115-711B-5H & $0^{\circ}$ \\
\hline $115-710 \mathrm{~A}-11 \mathrm{H}$ & $255^{\circ}$ & $115-711 \mathrm{~B}-6 \mathrm{H}$ & $290^{\circ}$ \\
\hline $115-710 \mathrm{~A}-12 \mathrm{H}$ & $300^{\circ}$ & 115-711B-7H & * \\
\hline $115-710 \mathrm{~A}-13 \mathrm{H}$ & $50^{\circ}$ & $115-711 \mathrm{~B}-8 \mathrm{H}$ & $200^{\circ}$ \\
\hline $115-710 \mathrm{~B}-1 \mathrm{H}$ & $290^{\circ}$ & $115-711 \mathrm{~B}-9 \mathrm{H}$ & $145^{\circ}$ \\
\hline 115-710B-2H & $250^{\circ}$ & 115-711B-10H & $120^{\circ}$ \\
\hline $115-710 \mathrm{~B}-3 \mathrm{H}$ & $270^{\circ}$ & $115-711 \mathrm{~B}-11 \mathrm{H}$ & $60^{\circ}$ \\
\hline $115-710 \mathrm{~B}-4 \mathrm{H}$ & $270^{\circ}$ & & \\
\hline
\end{tabular}

Note: No interpretation was made for cores marked ${ }^{*}$ and so an arbitrary rotation $\left(270^{\circ}\right)$ is used for plotting.

but at a shallower angle. Principal component analysis (Kirschvink, 1980) of the high-coercivity component from all 32 samples taken gave well-defined directions having, for the most part, moderate inclinations (Table 3 ).

It seems likely that the low-coercivity component, being directed nearly vertically, must have been acquired during coring or perhaps during some stage of core processing aboard ship. The high-coercivity component, however, appears to be primary. This assertion is supported by two observations: first, this component is always directed downward; thus, it cannot be recording the present-day field (which points upward approximately $45^{\circ}$ at this Southern Hemisphere site). Second, there appears to be a consistent relationship between the declination of the high-coercivity component and the bedding dip seen in cores from Hole 706A (Fig. 6). Were this component generated by drilling or by some later processing in the lab, the declination

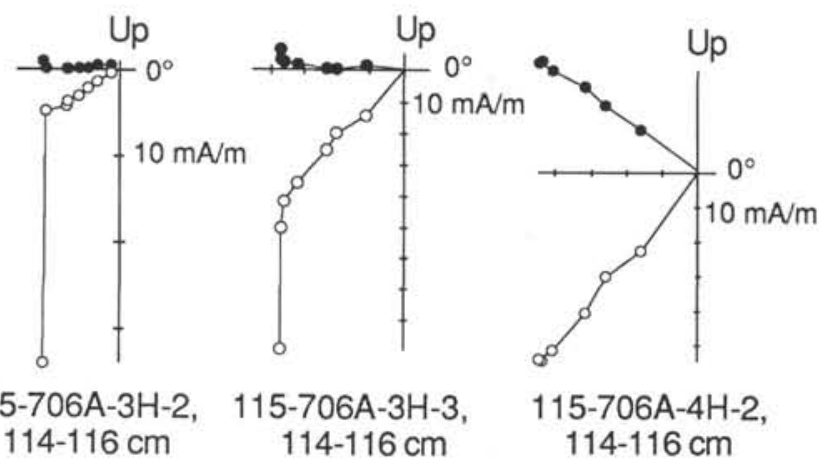

Figure 5. Orthogonal demagnetization diagrams for three representative samples from Site 706. Open dots show projection on vertical plane, closed dots show projection on horizontal plane. Demagnetization is by alternating fields ranging to $85 \mathrm{mT}$.
Table 3. Primary magnetization directions in discrete samples from Site 706.

\begin{tabular}{|c|c|c|c|c|c|}
\hline \multirow[b]{2}{*}{ Sample } & \multirow[b]{2}{*}{ MAD } & \multicolumn{2}{|c|}{ Geographic } & \multicolumn{2}{|c|}{ Tilt corrected } \\
\hline & & Declination & Inclination & Declination & Inclination \\
\hline \multicolumn{6}{|l|}{ 115-706A- } \\
\hline $2 \mathrm{H}-4,114$ & 3.6 & 215.5 & 29.2 & 215.5 & 29.2 \\
\hline $2 \mathrm{H}-5,114$ & 0.8 & 208.7 & 41.5 & 208.7 & 41.5 \\
\hline $2 \mathrm{H}-6,42$ & 3.3 & 175.1 & 70.3 & 175.1 & 70.3 \\
\hline $3 \mathrm{H}-1,114$ & 2.8 & 175.3 & 47.8 & 180.8 & 48.0 \\
\hline $3 \mathrm{H}-2,114$ & 3.4 & 180.7 & 33.0 & 183.8 & 17.3 \\
\hline $3 \mathrm{H}-3,114$ & 1.7 & 182.5 & 47.4 & 184.3 & 33.6 \\
\hline $3 \mathrm{H}-4,114$ & 1.2 & 169.2 & 50.6 & 177.7 & 43.0 \\
\hline $3 \mathrm{H}-5,114$ & 3.3 & 177.5 & 43.9 & 183.3 & 35.4 \\
\hline $3 \mathrm{H}-6,58$ & 2.8 & 173.6 & 56.7 & 183.2 & 48.4 \\
\hline $4 \mathrm{H}-1,114$ & 3.6 & 222.7 & 50.4 & 222.2 & 39.4 \\
\hline $4 \mathrm{H}-2,114$ & 1.1 & 216.0 & 44.8 & 219.3 & 36.7 \\
\hline $4 \mathrm{H}-3,114$ & 1.0 & 291.7 & 41.9 & 284.7 & 26.9 \\
\hline $4 \mathrm{H}-4,114$ & 3.2 & 96.6 & 58.0 & 119.1 & 73.3 \\
\hline $4 \mathrm{H}-5,94$ & 4.7 & 253.7 & 52.7 & 253.8 & 34.7 \\
\hline $5 \mathrm{H}-1,114$ & 3.4 & 264.7 & 51.2 & 258.1 & 32.5 \\
\hline $5 \mathrm{H}-2,114$ & 1.6 & 247.2 & 54.7 & 249.9 & 36.9 \\
\hline $5 \mathrm{H}-6,114$ & 1.2 & 263.5 & 53.9 & 261.1 & 42.1 \\
\hline $6 \mathrm{H}-1,114$ & 2.5 & 34.0 & 36.2 & 47.0 & 32.7 \\
\hline $6 \mathrm{H}-2,114$ & 1.9 & 105.0 & 38.6 & 95.3 & 25.7 \\
\hline \multicolumn{6}{|l|}{$115-706 \mathrm{~B}-$} \\
\hline $1 \mathrm{H}-3,114$ & 1.6 & 93.3 & 39.6 & 94.6 & 34.9 \\
\hline $1 \mathrm{H}-4,85$ & 1.9 & 90.1 & 37.6 & 91.5 & 33.0 \\
\hline $2 \mathrm{H}-1,114$ & 3.1 & 334.9 & 24.8 & 335.8 & 25.6 \\
\hline $2 \mathrm{H}-3,114$ & 2.4 & 323.9 & 47.5 & 323.9 & 47.5 \\
\hline $2 \mathrm{H}-4,114$ & 2.1 & 326.2 & 24.4 & 326.2 & 24.4 \\
\hline $2 \mathrm{H}-5,54$ & 4.0 & 330.5 & 36.4 & 330.5 & 36.4 \\
\hline $3 \mathrm{H}-1,98$ & 2.4 & 215.4 & 49.8 & 208.0 & 45.5 \\
\hline $3 \mathrm{H}-2,98$ & 3.7 & 227.5 & 32.3 & 222.9 & 29.7 \\
\hline $3 \mathrm{H}-3,98$ & 1.3 & 212.9 & 31.1 & 211.2 & 26.0 \\
\hline $3 \mathrm{H}-4,98$ & 1.1 & 226.4 & 38.2 & 223.3 & 33.9 \\
\hline $3 \mathrm{H}-5,98$ & 1.1 & 209.6 & 37.9 & 207.6 & 32.6 \\
\hline $4 \mathrm{H}-1,112$ & 2.7 & 8.5 & 2.8 & 8.3 & 3.2 \\
\hline $6 X-2,114$ & 3.1 & 165.6 & 46.3 & 169.8 & 47.2 \\
\hline
\end{tabular}

Note: MAD = mean angular deviation of vector determined by principal component analysis of progressive AF demagnetization results. Declination values are given with respect to the double fiducial line on core liner. Tilt correction uses the bedding orientation as measured in the core at the point closest to the sample where bedding could be reliably determined.

should show no consistent relationship with bedding. Thus, the downward-directed, high-coercivity component appears to record a primary direction. Because plate reconstructions place this site in the Southern Hemisphere, this component corresponds to a reverse polarity interval.

Clearly, the issue of bedding tilt needs to be examined carefully as it influences the paleomagnetic inclination and ultimately the paleolatitude estimate for this site. We have removed the effects of the tilt using the following procedure: at several places in each core, apparent bedding dip was estimated on the core face and on a face cut perpendicular to this. True dip (measured with respect to the core liner) could then be determined. The results for cores from Hole $706 \mathrm{~A}$ show some $10^{\circ}-20^{\circ}$ of tilt in a direction close to the declination of the high-coercivity magnetization. Tilt directions determined in cores from Hole $706 \mathrm{~B}$, however, are nearly horizontal. Because these two holes are probably separated by no more than several tens of meters (the accuracy of the dynamic positioning system aboard the JOIDES Resolution being about $2 \%$ of the water depth or 50 $\mathrm{m})$, it seems that some structure must exist at this site. Our drilling in Hole 706A may have penetrated a tilted package of sediment, whereas largely undisturbed sediments were sampled in nearby Hole 706B. Microfaults within these sediments are steeply dipping and have normal offsets, suggesting that normal faulting may account for the local tilt. 


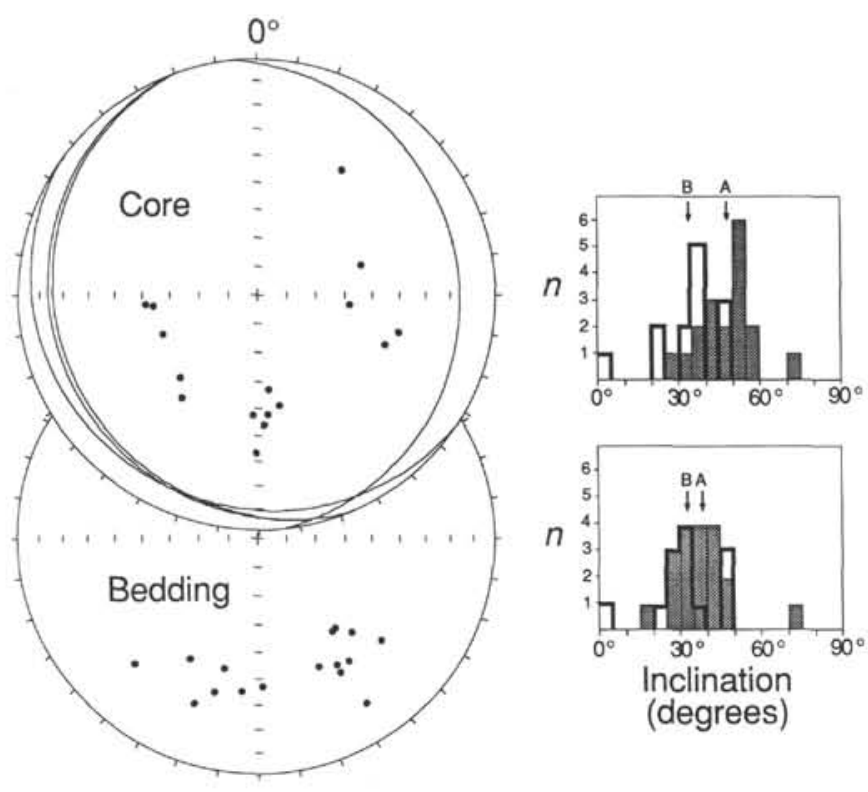

Figure 6. Directions of high-coercivity component (indicated by dots) in samples from Site 706 cores that showed bedding (indicated by great circles). Upper stereonet shows magnetization directions in arbitrary core coordinates (declination measured relative to core liner). Lower stereonet shows directions after adjusting declination in each core so as to give a consistent direction of bedding dip (set to $180^{\circ}$ ), and correcting inclination for this bedding tilt. Histograms at right show distribution of inclination before (upper) and after (lower) tilt correction. Arrows indicate the maximum likelihood estimate of mean inclination from Holes $706 \mathrm{~A}$ and $706 \mathrm{~B}$.

The variation in paleomagnetic inclination between the two holes is also consistent with a local tilt: the average inclination of the high-coercivity component determined from Hole 706A without tilt correction is $48.4^{\circ}\left(N=19 ; \alpha_{95}=5.6\right)$; the average inclination from Hole 706B is $34.5^{\circ}\left(N=13 ; \alpha_{95}=8.8\right)$, yielding a $13.9^{\circ}$ difference between the two holes. This difference is significant, because the confidence intervals on the inclinations ( 0.8 of the $\alpha_{95}$ values, according to Demarest, 1983) do not overlap. Correction for bedding tilt, however, reduces the average inclination for Hole $706 \mathrm{~A}$ to $38.4^{\circ}\left(\alpha_{95}=6.4\right)$ and brings the result into good agreement with the average inclination for Hole 706B, which is $33.1^{\circ}\left(\alpha_{95}=8.3\right)$, when corrected for the slight bedding dip. Because the mean inclination in Hole 706 $\mathrm{A}\left(38.4^{\circ}\right)$ clearly falls within the error bounds on inclination in Hole 706B $\left(33.1^{\circ} \pm 66^{\circ}\right)$, the paleomagnetic results from the two holes at Site 706 have, in a sense, passed a fold test (Fig. 6).

Although we did not observe mixed polarities at this site, the consistency of the paleomagnetic and bedding directions effectively rules out the possibility that the high-coercivity component is induced by coring or by later processing on board. Furthermore, the interpretation that this component reflects a primary magnetization acquired during one Oligocene reversed polarity chron is consistent with the biostratigraphy that places these sediments within the single nannoplankton Zone CP18 (Backman, Duncan, et al., 1988, pp. 132-137). For example, the presence of Sphenolithus distensus and absence of Sphenolithus ciperoensis from the entire sequence would suggest that these sediments were deposited within a particularly short interval. At DSDP Site 558 in the North Atlantic, $S$. distensus first occurs in the lowermost portion of Chron C12R (35 Ma), whereas $S$. ciperoensis first occurs near the base of $\mathrm{C} 11 \mathrm{~N}(\sim 32 \mathrm{Ma})$ (Miller et al., 1985). The uniformly reversed polarity Oligocene sequence recovered at Site 706 probably corresponds to either C11R (32.1-32.5 Ma) or C12R (32.9-35.3 Ma). The latter interval, being much longer, seems a more likely assignment. Radiometric dating of the basement rocks at $33.2 \mathrm{Ma}$ agrees with the age range estimated from paleomagnetism and biostratigraphy of these sediments; however, minor adjustments to the absolute age assignments of Berggren et al. (1985a, 1985b) were suggested by Duncan and Hargraves (this volume) on the basis of results from the basement drilling. The average inclination for this site (after correcting the results for bedding tilt) is $36.3^{\circ}$ ( $N$ $\left.=32 ; \kappa=25.3 ; \alpha_{95}=5.1^{\circ}\right)$. Using the geocentric axial dipole assumption, this average inclination corresponds to a paleolatitude of $20.2^{\circ}$. The allowable paleolatitude range, considering the $95 \%$ confidence interval on inclination, is between $17.5^{\circ}$ and $23.0^{\circ}$.

\section{Site 707}

Site 707 is located at $7^{\circ} 33^{\prime} \mathrm{S}, 59^{\circ} 1^{\prime} \mathrm{E}$ in the topographic saddle between the Seychelles and Saya de Malha banks at $1552 \mathrm{~m}$ water depth. Nearly $400 \mathrm{~m}$ of section, Paleocene to Holocene in age, was recovered before intercepting basement. Shipboard PTM measurements of the APC cores revealed pervasive rust contamination, the effects of which dominated the low intrinsic magnetization of the high-carbonate Neogene sediments. Discrete samples are generally free from rust; however, the magnetic moment of these samples is typically too weak to be measured reliably, even on a shore-based cryogenic magnetometer. For example, measurement of one discrete sample from each APC core of Hole 707A showed that the natural remanent magnetization (NRM) in these sediments is typically less than 0.01 $\mathrm{mA} / \mathrm{m}$. With the exception of a few discrete samples that proved more intensely magnetized (Backman, Duncan, et al., 1988, pp. 252-259), no reliable paleomagnetic data are available from this site.

\section{Site 708}

Site 708 is located east of the Seychelles Bank at $5^{\circ} 28^{\prime} \mathrm{S}$, $59^{\circ} 56^{\prime} \mathrm{E}$ at $4109 \mathrm{~m}$ water depth. The $236-\mathrm{m}$ section of nannofossil ooze recovered spans the early Oligocene to the Holocene. The sediments at Site 708 contain numerous high-carbonate turbidites (presumably shed from the nearby Seychelles Bank). From the single hole drilled, eight cores were taken using the APC. The PTM measurements of the eight APC cores produced erratic results, probably caused by rust contamination and core barrel remagnetization. Nevertheless, discrete samples taken from pelagic intervals within these cores give paleomagnetic results that appear stable under AF demagnetization (Fig. 7) and have inclinations consistent with the anticipated paleolatitude for this site. Where possible, we have assigned polarity to each of the discrete samples taken from the eight APC cores of Hole 708A. The scarcity of reliable datum levels, however, prevents us from attempting any correlation of the resultant crude magnetostratigraphy (Fig. 8) with the GPTS.

\section{Site 709}

Site 709 is situated at $3^{\circ} 55^{\prime} \mathrm{S}, 60^{\circ} 33^{\prime} \mathrm{E}$ on the Madingley Rise, a local topographic high between the Mascarene Plateau and the Carlsberg Ridge. Three holes were drilled at this site, recovering a particularly homogeneous section of nannofossil ooze and chalk, ranging in age from the Eocene to the Holocene. Relatively little paleomagnetic work was done on sediments from Hole 709C, after the measurements from the first two holes indicated largely erratic results. Several factors contribute to the poor results: the sediments from 35 to $\sim 120 \mathrm{mbsf}$ are too weakly magnetized to be measured reliably; furthermore, the more highly magnetized sediments below $120 \mathrm{mbsf}$ were severely disturbed by remagnetization during coring (Back- 


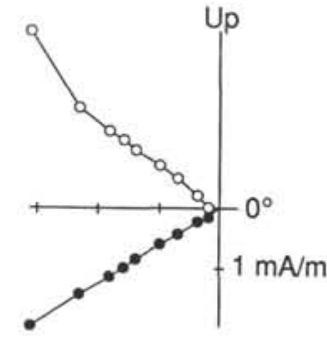

$115-708 \mathrm{~A}-1 \mathrm{H}-2$, $114-116 \mathrm{~cm}$

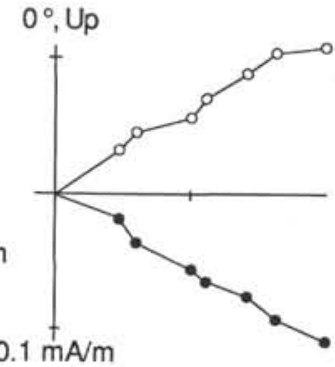

115-708A-7H-7, $57-59 \mathrm{~cm}$

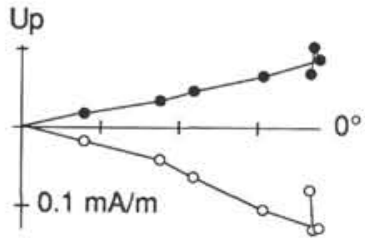

$115-708 \mathrm{~A}-8 \mathrm{H}-2$ $114-116 \mathrm{~cm}$

Figure 7. Orthogonal demagnetization diagrams for three representative samples from Site 708. Open dots show projection on vertical plane, closed dots show projection on horizontal plane. Demagnetization is by alternating fields ranging to $80 \mathrm{mT}$.

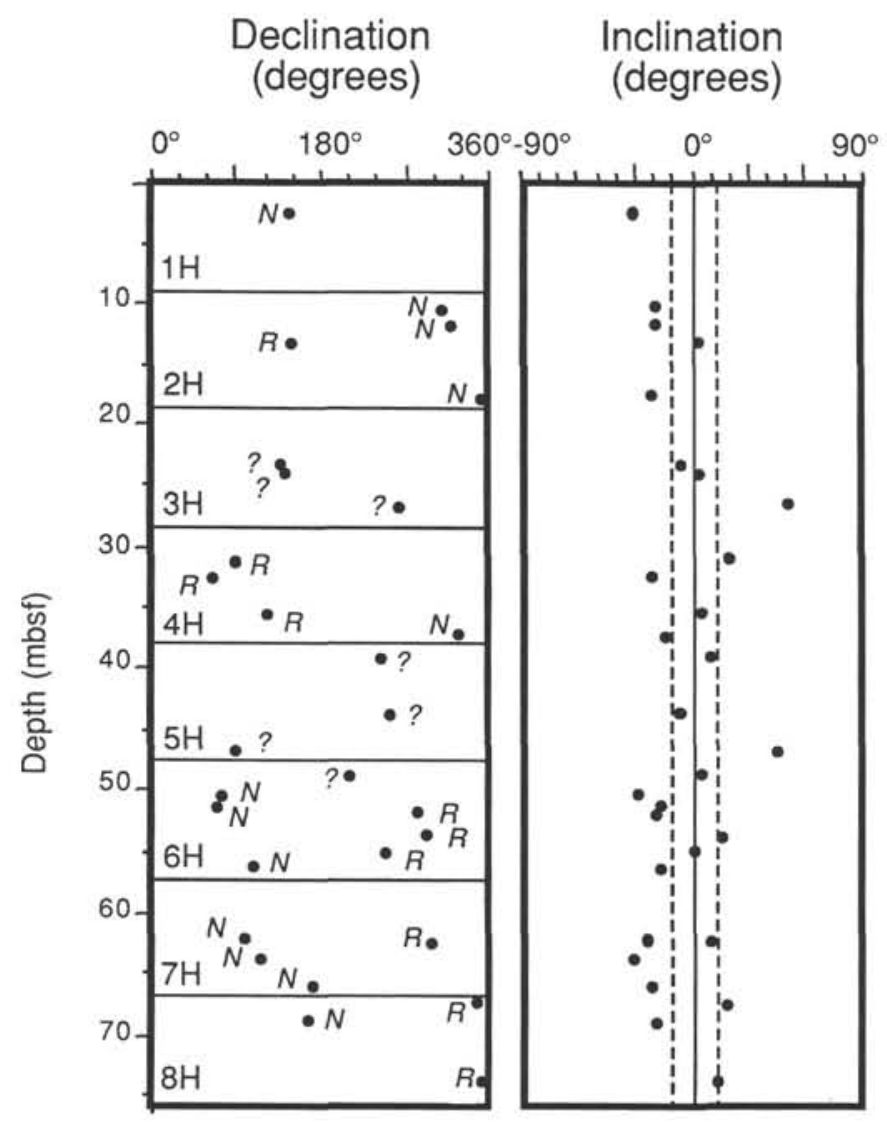

Figure 8. Paleomagnetic directions from discrete samples taken from APC cores of Hole 708A. Polarity of any individual sample in one APC core (shown as $\mathrm{N}$ for normal or $\mathrm{R}$ for reverse) is assigned so as to give greatest consistency to the inclination results for all samples from that core. Solid horizontal lines on declination panel indicate breaks between cores. Dotted lines on inclination panel show dipole inclination for the present-day site latitude.

man, Duncan, et al., 1988, pp. 475-476). We present here the magnetic polarity stratigraphy determined for only two small portions of the total section: from $\sim 15$ to $35 \mathrm{mbsf}$, corresponding to a 2-3-m.y. interval in the Pliocene-Pleistocene (Table 4), and from $\sim 170$ to $200 \mathrm{mbsf}$, corresponding perhaps to an interval of some $3 \mathrm{~m}$.y. near the Oligocene/Miocene boundary.
Table 4. Reversal boundary depths for Site 709 (PliocenePleistocene section).

\begin{tabular}{|c|c|c|c|c|}
\hline $\begin{array}{l}\text { Core, section, } \\
\text { interval }(\mathrm{cm})\end{array}$ & $\begin{array}{l}\text { Depth } \\
\text { (mbsf) }\end{array}$ & Sense & Interpretation & $\begin{array}{l}\text { Age } \\
\text { (Ma) }\end{array}$ \\
\hline \multicolumn{5}{|l|}{$115-709 \mathrm{~A}-$} \\
\hline $1 \mathrm{H}-6,150$ & 9.00 & $\mathrm{R}-\mathrm{N}$ & Brunhes/Matyama? & 0.73 \\
\hline $3 \mathrm{H}-2,15$ & 21.35 & $\mathrm{R}-\mathrm{N}$ & Olduvai (O) & 1.88 \\
\hline $3 \mathrm{H}-5,45$ & 26.05 & $\mathrm{~N}-\mathrm{R}$ & Matuyama/Gauss & 2.47 \\
\hline $4 \mathrm{H}-1,115$ & 30.55 & $\mathrm{R}-\mathrm{N}$ & Mammoth $(\mathrm{T})$ & 3.08 \\
\hline $4 \mathrm{H}-2,75$ & 31.65 & N-R & Mammoth (O) & 3.18 \\
\hline $4 \mathrm{H}-3,85$ & 33.25 & $\mathrm{R}-\mathrm{N}$ & Gauss/Gilbert & 3.40 \\
\hline \multicolumn{5}{|l|}{ 115-709B- } \\
\hline $3 \mathrm{H}-4,60$ & 18.50 & N-R & Olduvai $(\mathrm{T})$ & 1.66 \\
\hline $3 \mathrm{H}-5,70$ & 20.10 & R-N & Olduvai $(O)$ & 1.88 \\
\hline $4 \mathrm{H}-2,20$ & 24.80 & $\mathrm{~N}-\mathrm{R}$ & Matuyama/Gauss & 2.47 \\
\hline $4 \mathrm{H}-4,145$ & 29.05 & R-N & Kaena $(\mathrm{T})$ & 2.92 \\
\hline $4 \mathrm{H}-5,75$ & 29.85 & N-R & Kaena (O) & 2.99 \\
\hline $4 \mathrm{H}-6,15$ & 30.75 & R-N & Mammoth (T) & 3.08 \\
\hline $4 \mathrm{H}-6,105$ & 31.65 & $\mathrm{~N}-\mathrm{R}$ & Mammoth (O) & 3.18 \\
\hline
\end{tabular}

Note: $\mathrm{O}=$ onset and $\mathrm{T}=$ termination

The paleomagnetic results from the uppermost sediments cannot be interpreted with confidence. Core 115-709A-1H appears to show consistent declinations downcore (in both PTM and discrete samples) with a distinct $180^{\circ}$ shift in declination at 9 mbsf. Although this shift occurs exactly between two core sections, it may well record a genuine polarity reversal. Associating this declination shift with the Brunhes/Matuyama boundary (as we show in Fig. 9) is not unreasonable and would be consistent with a constant rate of sedimentation between the Brunhes/Matuyama boundary and two calcareous nannofossil datum events identified in Core 115-709C-1H: the first occurrence (FO) of Emiliania huxleyi $(0.27 \mathrm{Ma})$ at $2.4 \mathrm{mbsf}$ and the last occurrence (LO) of Pseudoemiliania lacunosa $(0.47 \mathrm{Ma})$ at $5.4 \mathrm{mbsf}$ (Backman, Duncan, et al., 1988, pp. 467-474). The PTM results in Cores $115-709 \mathrm{~A}-2 \mathrm{H}$ and $115-709 \mathrm{~B}-2 \mathrm{H}$ are highly scattered and show little consistency with discrete samples. In contrast, the magnetic reversal sequence determined in Cores 115-709A-3H and $-4 \mathrm{H}$ and Cores $115-709 \mathrm{~B}-3 \mathrm{H}$ and $-4 \mathrm{H}$ can be reasonably well correlated with that portion of the GPTS spanning approximately the early Matuyama, Gauss, and late Gilbert (Fig. 9). Note that, for presentation, the declinations have been rotated in each core so as to bring the declination of what are apparently normal polarity zones to $0^{\circ}$. In Cores $115-709 \mathrm{~A}-3 \mathrm{H}$ and 115-709B-3H, polarity sense can be assigned with reasonable assurance on the basis of the inclination determined from discrete 


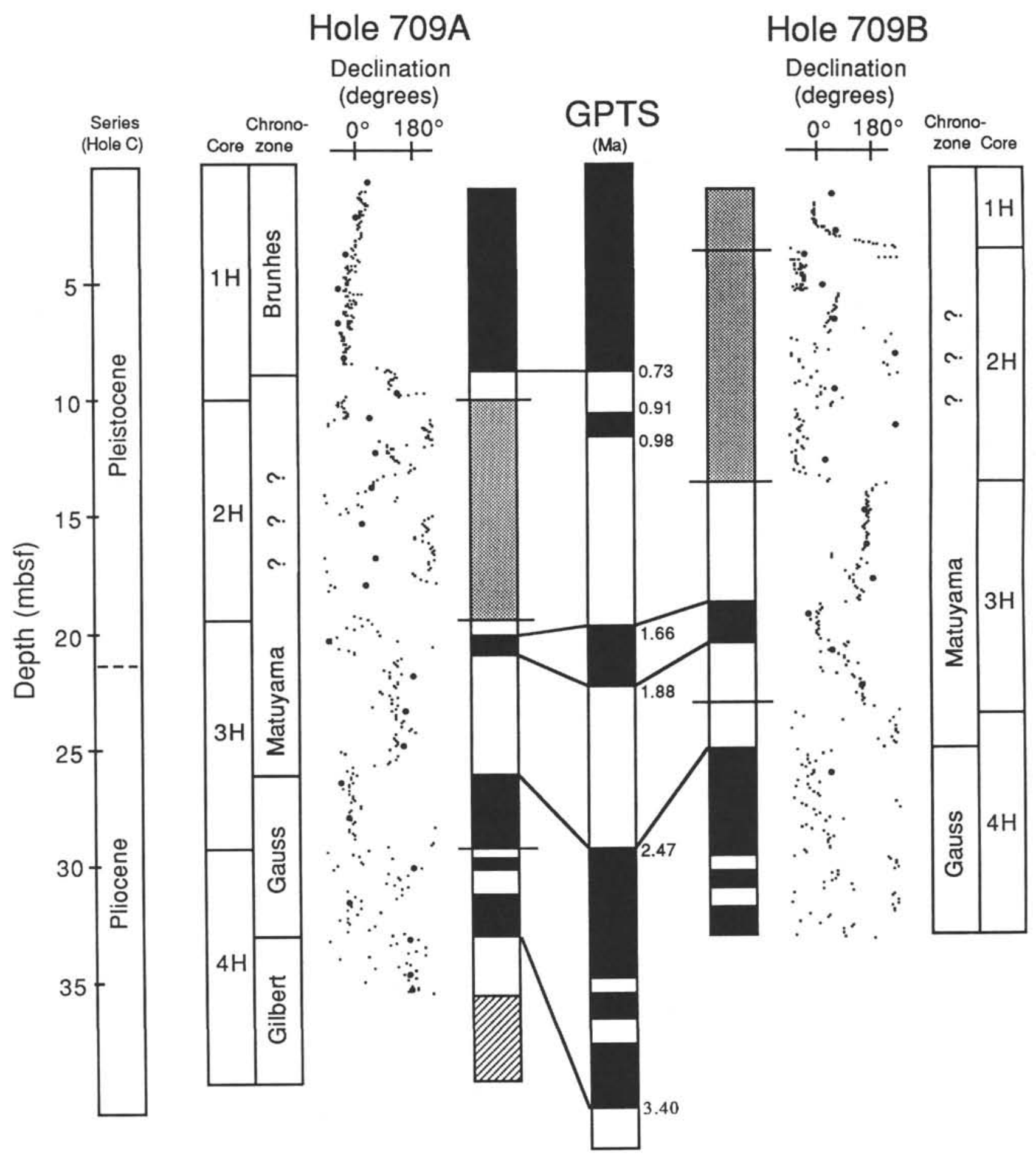

Figure 9. Magnetic polarity stratigraphy determined for the Pliocene-Pleistocene section of Site 709. Declinations have been adjusted to bring the declination of normal polarity zones to $0^{\circ}$. Smaller dots indicate PTM measurements; larger dots indicate results from discrete samples (after 15-mT alternating-field demagnetization). Black indicates chrons of normal polarity and white reversed polarity. Shading indicates that no interpretation is made. Hachures correspond to levels lacking data. The indicated series boundary, based on the nannofossil biostratigraphy of sediments from Hole $709 \mathrm{C}$, is approximate.

samples; however, in Cores 115-709A-4H and 115-709B-4H, the polarity sense cannot be so determined. We have made the polarity assignment that allows a consistent correlation between cores and with the GPTS.

The magnetostratigraphy of the $30-\mathrm{m}$ section spanning the Miocene/Oligocene boundary is constructed from the paleo- magnetic record of three APC cores: $115-709 \mathrm{C}-19 \mathrm{H},-20 \mathrm{H}$, and $-21 \mathrm{H}$ (Fig. 10). We venture an interpretation of magnetic polarity zones for these three cores because the behavior of the discrete samples suggests that they are recording a primary magnetization. Inclinations are moderately shallow, consistent with the expected paleolatitudes for this site. Also, the sign changes 




Figure 10. Magnetic polarity stratigraphy determined for the OligoceneMiocene section of Site 709. The inclination determined from discrete samples is shown; otherwise, plotting conventions are as in Figure 9.

in the inclination measured in discrete samples correspond to $180^{\circ}$ shifts in declination and probably indicate the presence of two polarities. The PTM records from these three cores, however, appear erratic in both declination and inclination, caused most probably by the core barrel remagnetization that so obviously affected many cores from this site.

Nevertheless, by using the PTM record judiciously, we can construct a tentative magnetostratigraphy with considerably better resolution than the $1.5-\mathrm{m}$ interval between discrete samples. This polarity stratigraphy (Fig. 10) shows a relatively long normal polarity zone in the top half of Core $115-709$ C-19H (169.9$174.5 \mathrm{mbsf}$ ), which may possibly correlate with Chron C6N. The FO of the nannofossil Sphenolithus belemnos is placed in the upper third of this core (Backman, Duncan, et al., 1988, pp. 467-474), and this datum has been correlated with Chron C6N in the North Atlantic (Miller et al., 1985). The observation of the LO of the nannofossil S. ciperoensis near $200 \mathrm{mbsf}$ in Site 709 (which is associated with Chron C7 by Miller et al., 1985) suggests that the three normal zones identified in Core 115709A-21H may perhaps correlate with Chrons C7 and C7A. However, given the difficulty recovering reliable paleomagnetic data from this hole, we must regard these correlations as being tentative.

\section{Site 710}

Site 710 is located at $4^{\circ} 19^{\prime} \mathrm{S}, 60^{\circ} 59^{\prime} \mathrm{E}$ to the north and east of the Saya de Malha and Seychelles banks, in $3812 \mathrm{~m}$ water depth. A section of slightly more than $200 \mathrm{~m}$ of nannofossil ooze and chalk was recovered from two holes. Of the 20 APC cores recovered at this site, all but two provide a paleomagnetic reversal stratigraphy that can be readily interpreted for magnetic polarity and reasonably correlated with the magnetic polarity time scale.

As was the case at other sites, core barrel remagnetization commonly contaminates the inclination measured with the PTM system. Nevertheless, reversals can be easily detected from the record of declination shifts. Polarity sense in each core is determined either from the inclination in remagnetization-free intervals in the PTM record of that core or by the inclination measured in discrete samples. Lacking reliable azimuthal orientation, we cannot be absolutely certain in our determination of polarity for all cores from this low-latitude site. We have confidence, however, that our determination of the overall polarity sense is correct for most of the 20 APC cores analyzed.

Interpretation of the many short polarity intervals indicated by the PTM record is problematic, especially because some of these may be artifacts of the PTM response itself (as discussed above). We have, however, made our best estimates as to which of these features reflect short polarity intervals.

The results from the two holes drilled at Site 710 (Fig. 11) show a total of 78 magnetozone boundaries, most of which we have attempted to correlate with the magnetic polarity time scale (Table 5). Discrete samples taken from these cores were all subjected to progressive AF demagnetization and, in the large majority of cases, gave directions that confirm the PTM results (Table 6) and establish polarity sense for those cores for which this was otherwise unclear.

Interpretation of the data from Site 710 in terms of magnetic polarity is, for the most part, straightforward; however, correlation of the polarity pattern so determined to the GPTS is more difficult, in part because of substantial changes in sedimentation rate as well as gaps where the magnetostratigraphy proved impossible to recover. In particular, Core 115-710A-10H, which contains slumped and probably overturned sediments (Backman, Duncan, et al., 1988, pp. 593-597) rendered a confused paleomagnetic record that we did not attempt to interpret. The upper half of Core $115-710 \mathrm{~A}-8 \mathrm{H}$ is also difficult to correlate with the magnetic polarity time scale. Here again, visual as well as biostratigraphic analysis of this core (Backman, Duncan, et al., 1988, pp. 597-602) shows that this section is composed of slumped or reworked material, and we suspect that this slumping may have disturbed the paleomagnetic record.

A more enigmatic problem occurs in Core $115-710 \mathrm{~A}-4 \mathrm{H}$, in which no obvious physical disturbance is present. Measurements on this core appear to record five normal polarity subchrons within the Gilbert. Biostratigraphic analysis shows that the core does not sample Gauss-age sediments because the top of calcareous nannoplankton Zone NN15 is not found within this core. It seems most likely that the apparent normal polarity interval between 31 and 32 mbsf is spurious. The interval is associated with a suspiciously large intensity spike in this core, al- 
Hole 710A



Hole 710B

Declination (degrees) $0^{\circ} 180^{\circ}$ zone Core

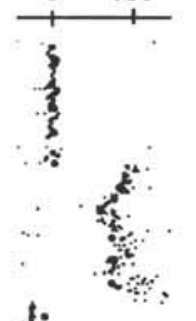

\$.;<smiles>C[14CH2][14CH2]</smiles>

$\ddot{\xi}$

f

$\therefore,-2$

$\therefore$ n

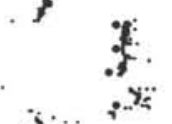

i. i

s.

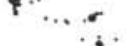

. …

$\because 8$

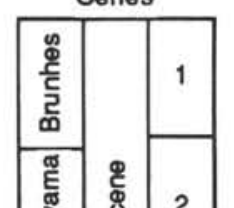

$\therefore$
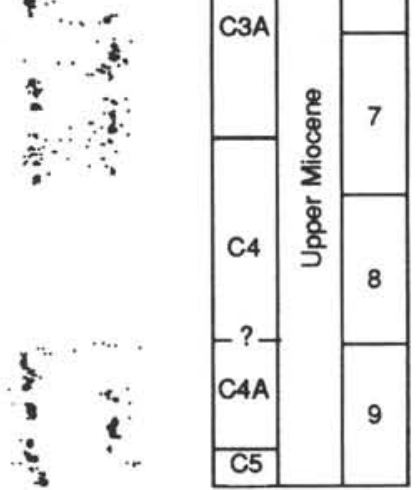

Figure 11. Magnetic polarity stratigraphy determined for Site 710. Discrete sample results (larger dots) represent progressive alternatingfield demagnetization; otherwise, conventions are as in Figure 9. 
Table 5. Reversal boundary depths for Site $\mathbf{7 1 0}$.

\begin{tabular}{|c|c|c|c|c|}
\hline $\begin{array}{l}\text { Core, section, } \\
\text { interval }(\mathrm{cm})\end{array}$ & $\begin{array}{l}\text { Depth } \\
\text { (mbsf) }\end{array}$ & Sense & Interpretation & $\begin{array}{l}\text { Age } \\
(\mathrm{Ma})\end{array}$ \\
\hline \multicolumn{5}{|l|}{$115-710 \mathrm{~A}-$} \\
\hline $1 \mathrm{H}-5,50$ & 6.5 & $\mathrm{R}-\mathrm{N}$ & Brunhes/Matuyama & 0.73 \\
\hline $2 \mathrm{H}-4,140$ & 15.4 & N-R & Olduvai $(T)$ & 1.66 \\
\hline $3 \mathrm{H}-1,90$ & 20.1 & N-R & Matuyama/Gauss & 2.47 \\
\hline $4 \mathrm{H}-1,110$ & 29.9 & $\mathrm{R}-\mathrm{N}$ & Cochiti $(O)$ & 3.97 \\
\hline $4 \mathrm{H}-2,100$ & 31.3 & N-R & Spurious? & \\
\hline $4 \mathrm{H}-4,0$ & 33.3 & N-R & Nunivak (T) & 4.10 \\
\hline $4 \mathrm{H}-4,90$ & 34.2 & R-N & Nunivak (O) & 4.24 \\
\hline $4 \mathrm{H}-5,110$ & 35.9 & N-R & Sidufjall (T) & 4.40 \\
\hline $4 \mathrm{H}-6,70$ & 37.0 & $\mathrm{R}-\mathrm{N}$ & Sidufjall $(\mathrm{O})$ & 4.47 \\
\hline $4 \mathrm{H}-7,0$ & 37.8 & $\mathrm{~N}-\mathrm{R}$ & Thvera $(\mathrm{T})$ & 4.57 \\
\hline $6 \mathrm{H}-2,30$ & 49.7 & N-R & $\mathrm{C} 3 \mathrm{AN} 2(\mathrm{~T})$ & 5.68 \\
\hline $6 \mathrm{H}-4,20$ & 52.0 & R-N & C3AN2 (O) & 5.89 \\
\hline $7 \mathrm{H}-2,130$ & 60.3 & N-R & C4N1 (T) & 6.70 \\
\hline $7 \mathrm{H}-3,110$ & 61.6 & $\mathrm{R}-\mathrm{N}$ & $\mathrm{C} 4 \mathrm{~N} 1(\mathrm{O})$ & 6.78 \\
\hline $7 \mathrm{H}-4,10$ & 62.1 & $\mathrm{~N}-\mathrm{R}$ & $\mathrm{C} 4 \mathrm{~N} 2(\mathrm{~T})$ & 6.85 \\
\hline $7 \mathrm{H}-6,120$ & 66.2 & $\mathrm{R}-\mathrm{N}$ & $\mathrm{C} 4 \mathrm{~N} 3(\mathrm{O})$ & 7.41 \\
\hline $8 \mathrm{H}-5,110$ & 74.2 & N-R & C4ANI (T) & 7.90 \\
\hline $8 \mathrm{H}-6,0$ & 74.6 & $\mathrm{R}-\mathrm{N}$ & ? & \\
\hline $8 \mathrm{H}-6,20$ & 74.8 & $\mathrm{~N}-\mathrm{R}$ & ? & \\
\hline $9 \mathrm{H}-1,70$ & 77.3 & N-R & C4AN2 (T) & 8.41 \\
\hline $9 \mathrm{H}-2,0$ & 78.1 & $\mathrm{R}-\mathrm{N}$ & C4AN2 (O) & 8.50 \\
\hline $9 \mathrm{H}-2,120$ & 79.3 & N-R & C4AN3 (T) & 8.71 \\
\hline $9 \mathrm{H}-3,10$ & 79.7 & $\mathrm{R}-\mathrm{N}$ & C4AN3 (O) & 8.80 \\
\hline $9 \mathrm{H}-3,40$ & 80.0 & N-R & C5N1 (T) & 8.92 \\
\hline $9 \mathrm{H}-6,60$ & 84.7 & $\mathrm{R}-\mathrm{N}$ & $\mathrm{C} 5 \mathrm{~N} 1$ or $\mathrm{N} 2(\mathrm{O})$ & \\
\hline $11 \mathrm{H}-2,120$ & 98.5 & $\mathrm{R}-\mathrm{N}$ & $\mathrm{C} 5 \mathrm{ACN}(\mathrm{O})$ & 14.08 \\
\hline $11 \mathrm{H}-3,30$ & 99.1 & N-R & CSADN (T) & 14.20 \\
\hline $11 \mathrm{H}-5,50$ & 102.3 & $\mathrm{R}-\mathrm{N}$ & C5ADN (T) & 14.66 \\
\hline $11 \mathrm{H}-7,0$ & 104.8 & N-R & C5BN1 $(\mathrm{T}) ?$ & 14.87 \\
\hline $11 \mathrm{H}-7,40$ & 105.2 & $\mathrm{R}-\mathrm{N}$ & C5BN1 $(\mathrm{O}) ?$ & 14.96 \\
\hline $12 \mathrm{H}-3,120$ & 109.7 & N-R & $\mathrm{C} 5 \mathrm{CN} 1(\mathrm{~T})$ & 16.22 \\
\hline $12 \mathrm{H}-5,20$ & 111.7 & R-N & $\mathrm{C} 5 \mathrm{CN} 3(\mathrm{O})$ & 16.98 \\
\hline $12 \mathrm{H}-5,130$ & 112.8 & N-R & C5DN1 (T) & 17.57 \\
\hline $12 \mathrm{H}-6,30$ & 113.3 & R-N & C5DN1 or N2 (O) & \\
\hline $12 \mathrm{H}-7,20$ & 114.7 & N-R & C5EN (T)? & 18.56 \\
\hline $13 \mathrm{H}-1,50$ & 115.7 & N-R & $\mathrm{C} 6 \mathrm{~N}(\mathrm{~T})$ & 19.35 \\
\hline $13 \mathrm{H}-3,30$ & 118.5 & $\mathrm{R}-\mathrm{N}$ & $\mathrm{C} 6 \mathrm{~N}(\mathrm{O})$ & 20.45 \\
\hline $13 \mathrm{H}-3,140$ & 119.6 & N-R & C6AN1 (T) & 20.88 \\
\hline $13 \mathrm{H}-4,30$ & 120.0 & $\mathrm{R}-\mathrm{N}$ & C6AN1 (O) & 21.16 \\
\hline $13 \mathrm{H}-4,90$ & 120.6 & N-R & C6AN2 (T) & 21.38 \\
\hline $13 \mathrm{H}-5,50$ & 121.7 & R-N & C6AN2 (O) & 21.71 \\
\hline $13 \mathrm{H}-6,10$ & 122.8 & N-R & C6AAN1 (T)? & 21.90 \\
\hline
\end{tabular}

though the corresponding interval seen in Core $115-710 \mathrm{~B}-4 \mathrm{H}$ shows no anomalous intensity. This feature probably reflects an unseen physical disturbance of the sediments rather than a true normal polarity zone, which would demand an unreasonable revision to a well-established portion of the magnetic polarity time scale.

Correlation of the reversal record in Site 710 sediments to the GPTS shown in Figure 11 and Table 5 is constrained by nannofossil biostratigraphy (Backman et al., this volume). For example, biostratigraphic analysis revealed that drilling did not properly advance after taking Core $115-710 \mathrm{~B}-2 \mathrm{H}$, so that the same interval was cored twice. This resulted in a duplication of the Brunhes/Matuyama boundary in Cores 115-710B-2H and -3H. Lower in the section, nannofossil biostratigraphy confirms that the lower Gilbert was recovered in Core 115-710B-5H because the FO of Ceratolithus rugosus, which appeared near the end of the Thvera Subchron (Backman and Shackleton, 1983), is found at $39.5 \mathrm{~m}$ in Hole 710B. The correlation of upper Miocene intervals is controlled by several nannofossil datums: the FO of Amaurolithus primus at $60.6 \mathrm{~m}$ (both holes) supports the identification shown for $\mathrm{C} 3 \mathrm{~A}$; the $\mathrm{FO}$ of Discoaster quinqueramus at the base of Core 115-710A-7 $\mathrm{H}$ confirms the correlation with $\mathrm{C} 4$; and the presence of several markers in Core 115-710A-9H (LO of Discoaster hamatus, LO of Catinaster spp., and FO of Discoaster neohamatus) indicates that the relatively thick normal zone in this core likely corresponds to Chron C5.
Table 5 (Continued).

\begin{tabular}{|c|c|c|c|c|}
\hline $\begin{array}{l}\text { Core, section, } \\
\text { interval }(\mathrm{cm})\end{array}$ & $\begin{array}{l}\text { Depth } \\
\text { (mbsf) }\end{array}$ & Sense & Interpretation & $\begin{array}{l}\text { Age } \\
(\mathrm{Ma})\end{array}$ \\
\hline \multicolumn{5}{|c|}{ 115-710A- (cont.) } \\
\hline $13 \mathrm{H}-6,40$ & 123.1 & $\mathrm{R}-\mathrm{N}$ & C6AAN1 $(\mathrm{O}) ?$ & 22.06 \\
\hline $13 \mathrm{H}-7,20$ & 124.4 & $N-R$ & C6AAN2 (T)? & 22.25 \\
\hline $13 \mathrm{H}-7,50$ & 124.7 & $\mathrm{R}-\mathrm{N}$ & C6AAN2 (O)? & 22.35 \\
\hline \multicolumn{5}{|l|}{$115-710 \mathrm{~B}-$} \\
\hline $2 \mathrm{H}-1,120$ & 7.7 & R-N & Brunhes/Matuyama & 0.73 \\
\hline $3 \mathrm{H}-3,80$ & 20.0 & $\mathrm{R}-\mathrm{N}$ & Brunhes/Matuyama & 0.73 \\
\hline $4 \mathrm{H}-1,20$ & 26.0 & N-R & Kaena $(\mathrm{O})$ & 2.99 \\
\hline $4 \mathrm{H}-1,40$ & 26.2 & $\mathrm{R}-\mathrm{N}$ & Mammoth $(\mathrm{T})$ & 3.08 \\
\hline $4 \mathrm{H}-1,90$ & 26.7 & $\mathrm{~N}-\mathrm{R}$ & Mammoth $(\mathrm{O})$ & 3.18 \\
\hline $4 \mathrm{H}-2,100$ & 28.3 & $\mathrm{R}-\mathrm{N}$ & Gauss/Gilbert & 3.40 \\
\hline $4 \mathrm{H}-5,20$ & 32.0 & $\mathrm{~N}-\mathrm{R}$ & Cochiti (T) & 3.88 \\
\hline $4 \mathrm{H}-5,130$ & 33.1 & $\mathrm{R}-\mathrm{N}$ & Cochiti (O) & 3.97 \\
\hline $4 \mathrm{H}-6,130$ & 34.6 & $\mathrm{~N}-\mathrm{R}$ & Spurious? & \\
\hline $5 \mathrm{H}-1,90$ & 36.2 & N-R & Sidufjall (T) & 4.40 \\
\hline $5 \mathrm{H}-2,50$ & 37.3 & $\mathrm{R}-\mathrm{N}$ & Sidufjall (O) & 4.47 \\
\hline $5 \mathrm{H}-2,130$ & 38.1 & N-R & Thvera (T) & 4.57 \\
\hline $5 \mathrm{H}-4,90$ & 40.7 & $\mathrm{R}-\mathrm{N}$ & Thvera (O) & 4.77 \\
\hline $6 \mathrm{H}-2,50$ & 46.9 & N-R & $\mathrm{C} 3 \mathrm{AN} 1$ (T) & 5.35 \\
\hline $6 \mathrm{H}-3,130$ & 49.2 & R-N & $\mathrm{C} 3 \mathrm{AN} 1(\mathrm{O})$ & 5.53 \\
\hline $6 \mathrm{H}-2,70$ & 50.1 & N-R & $?$ & \\
\hline $6 \mathrm{H}-2,90$ & 50.3 & R-N & $?$ & \\
\hline $6 \mathrm{H}-2,110$ & 50.5 & N-R & $\mathrm{C} 3 \mathrm{AN} 2(\mathrm{~T})$ & 5.68 \\
\hline $6 \mathrm{H}-4,50$ & 52.9 & R-N & C3AN2 (O) & 5.89 \\
\hline $7 \mathrm{H}-2,110$ & 57.1 & N-R & $\mathrm{C} 3 \mathrm{AN} 3(\mathrm{~T})$ & 6.37 \\
\hline $7 \mathrm{H}-3,70$ & 58.2 & R-N & $?$ & \\
\hline $7 \mathrm{H}-3,110$ & 58.6 & $\mathrm{~N}-\mathrm{R}$ & $?$ & \\
\hline $7 \mathrm{H}-4,0$ & 59.0 & $\mathrm{R}-\mathrm{N}$ & C3AN3 $(\mathrm{O})$ & 6.50 \\
\hline $7 \mathrm{H}-5,0$ & 60.5 & N-R & $?$ & \\
\hline $7 \mathrm{H}-5,20$ & 60.7 & R-N & $?$ & \\
\hline $7 \mathrm{H}-5,70$ & 61.2 & N-R & C4N1 (T) & 6.70 \\
\hline $7 \mathrm{H}-6,30$ & 62.3 & R-N & $\mathrm{C} 4 \mathrm{~N} 1(\mathrm{O})$ & 6.78 \\
\hline $7 \mathrm{H}-6,100$ & 63.0 & N-R & $\mathrm{C} 4 \mathrm{~N} 2$ (T) & 6.85 \\
\hline $9 \mathrm{H}-3,0$ & 76.8 & R-N & C4AN1 (O) & 8.21 \\
\hline $9 \mathrm{H}-3,70$ & 77.5 & N-R & C4AN2 (T) & 8.41 \\
\hline $9 \mathrm{H}-4,20$ & 78.5 & $\mathrm{R}-\mathrm{N}$ & C4AN2 (O) & 8.50 \\
\hline $9 \mathrm{H}-5,0$ & 79.8 & N-R & $\mathrm{C} 4 \mathrm{AN} 3(\mathrm{~T})$ & 8.71 \\
\hline $9 \mathrm{H}-5,50$ & 80.3 & R-N & C4AN3 (O) & 8.80 \\
\hline $9 \mathrm{H}-5,80$ & 80.6 & $\mathrm{~N}-\mathrm{R}$ & $\mathrm{C} 5 \mathrm{~N} 1(\mathrm{~T})$ & 8.92 \\
\hline
\end{tabular}

Note: $\mathrm{O}=$ onset and $\mathrm{T}=$ termination.

The correlation of the middle and lower Miocene intervals is not as well constrained; however, the interpretation shown most reasonably matches the reversal pattern determined in Cores $115-710 \mathrm{~A}-11 \mathrm{H},-12 \mathrm{H}$, and $-13 \mathrm{H}$ to the GPTS. In addition, the correlation we have adopted is consistent with the FO of Sphenolithus heteromorphus near the base of Core 115-710A-12H and with the FO of Discoaster druggii some $8 \mathrm{~m}$ below the base of Core 115-710A-13H.

Although the reversal pattern was satisfactorily recorded, the precise direction of magnetization is usually perturbed by core barrel remagnetization. Consequently, we chose to analyze only the least disturbed intervals in making inclination estimates. We used the PTM results (which, as discussed, are most sensitive to this remagnetization) to determine which intervals were least affected. These unaffected sections occur in Cores $115-710 \mathrm{~A}-6 \mathrm{H}$ and $-13 \mathrm{H}$ and Cores $115-710 \mathrm{~B}-5 \mathrm{H}$ and $-9 \mathrm{H}$. We can presume that discrete samples taken from these relatively unaffected intervals will be largely free from any overprint that cannot be removed (Fig. 12). Where possible, a large number of discrete samples were taken from these sections. Particulars of the resulting inclination averages for these four cores are shown in Table 7.

\section{Site 711}

Site 711 is located at $2^{\circ} 45^{\prime} \mathrm{S}, 61^{\circ} 10^{\prime} \mathrm{E}$ between the Madingley Rise and the Carlsberg Ridge at a water depth of 4430 $\mathrm{m}$. Two holes were drilled, and 22 APC cores were recovered. In 
Table 6. Progressive demagnetization results from discrete samples used in constructing magnetostratigraphy from Site 710.

\begin{tabular}{|c|c|c|c|c|c|c|c|c|c|c|c|}
\hline $\begin{array}{l}\text { Core, section, } \\
\text { interval }(\mathrm{cm})\end{array}$ & MAD & $\begin{array}{c}\text { Declination } \\
\text { (degrees) }\end{array}$ & $\begin{array}{l}\text { Inclination } \\
\text { (degrees) }\end{array}$ & $\begin{array}{l}\text { Core, section, } \\
\text { interval }(\mathrm{cm})\end{array}$ & MAD & $\begin{array}{c}\text { Declination } \\
\text { (degrees) }\end{array}$ & $\begin{array}{l}\text { Inclination } \\
\text { (degrees) }\end{array}$ & $\begin{array}{l}\text { Core, section, } \\
\text { interval }(\mathrm{cm})\end{array}$ & MAD & $\begin{array}{l}\text { Declination } \\
\text { (degrees) }\end{array}$ & $\begin{array}{l}\text { Inclination } \\
\text { (degrees) }\end{array}$ \\
\hline $115-710 \mathrm{~A}-$ & & & & 115-710A- (Cont & & & & $115-710 \mathrm{~B}-$ & & & \\
\hline $1 \mathrm{H}-1,114$ & 0.9 & 247.3 & -3.3 & $10 \mathrm{H}-2,146$ & 2.6 & 220.3 & -66.9 & $1 \mathrm{H}-1,114$ & 0.5 & 82.6 & -24.5 \\
\hline $1 \mathrm{H}-2,87$ & 0.4 & 236.0 & -7.8 & $10 \mathrm{H}-3,114$ & 1.8 & 344.7 & -7.7 & IH-2, 114 & 0.4 & 72.0 & -21.1 \\
\hline $1 \mathrm{H}-3,114$ & 0.3 & 219.2 & -26.8 & $10 \mathrm{H}-3,142$ & 2.2 & 346.6 & -3.2 & $1 \mathrm{H}-3,114$ & 0.4 & 76.0 & -18.8 \\
\hline $1 \mathrm{H}-4,114$ & 0.0 & 205.1 & -32.4 & $10 \mathrm{H}-4,20$ & 2.8 & 344.7 & -6.3 & $1 \mathrm{H}-4,114$ & 0.5 & 79.9 & -23.5 \\
\hline $1 \mathrm{H}-5,114$ & 5.1 & 17.0 & 35.0 & $10 \mathrm{H}-4,114$ & 0.4 & 171.1 & -9.9 & $2 \mathrm{H}-1,114$ & 0.6 & 114.6 & -9.8 \\
\hline $1 \mathrm{H}-6,114$ & 4.1 & 37.4 & -57.6 & $10 \mathrm{H}-5,50$ & 0.2 & 165.9 & -14.8 & $2 \mathrm{H}-2,114$ & 1.3 & 265.2 & 16.6 \\
\hline $2 \mathrm{H}-1,114$ & 2.0 & 233.7 & 5.5 & $10 \mathrm{H}-5,146$ & 1.0 & 5.7 & -47.5 & $2 \mathrm{H}-3,114$ & 1.2 & 223.7 & 6.3 \\
\hline $2 \mathrm{H}-2,114$ & 1.5 & 246.3 & 2.7 & $10 \mathrm{H}-6,4$ & 1.3 & 356.8 & -24.1 & $2 \mathrm{H}-4,133$ & 1.8 & 249.8 & 1.9 \\
\hline $2 \mathrm{H}-3,114$ & 2.6 & 219.7 & -3.1 & $10 \mathrm{H}-6,114$ & 1.5 & 339.4 & -17.1 & $2 \mathrm{H}-5,114$ & 1.2 & 251.3 & -2.9 \\
\hline $2 \mathrm{H}-4,114$ & 2.1 & 248.3 & -7.9 & $10 \mathrm{H}-7,46$ & 1.5 & 263.1 & -13.6 & $2 \mathrm{H}-6,114$ & 1.2 & 251.2 & 17.7 \\
\hline $2 \mathrm{H}-5,114$ & 3.8 & 147.1 & -34.6 & $11 \mathrm{H}-1,68$ & 5.2 & 245.2 & -8.3 & $3 \mathrm{H}-1,114$ & 0.9 & 76.8 & -18.1 \\
\hline $2 \mathrm{H}-6,114$ & 3.7 & 97.0 & -29.7 & $11 \mathrm{H}-1,114$ & 1.3 & 105.6 & 0.9 & $3 \mathrm{H}-2,114$ & 0.3 & 110.0 & -16.0 \\
\hline $3 \mathrm{H}-1,95$ & 3.1 & 72.8 & 37.7 & $11 \mathrm{H}-2,114$ & 4.4 & 253.8 & -44.0 & $3 \mathrm{H}-3,114$ & 3.3 & 340.9 & -6.3 \\
\hline $3 \mathrm{H}-2,95$ & 0.9 & 351.8 & -21.3 & $11 \mathrm{H}-3,114$ & 1.9 & 86.6 & 21.8 & $3 \mathrm{H}-5,114$ & 0.9 & 326.5 & -5.3 \\
\hline $3 \mathrm{H}-3,95$ & 0.4 & 356.8 & -12.7 & $11 \mathrm{H}-4,114$ & 0.8 & 129.4 & -9.2 & $3 \mathrm{H}-6,114$ & 1.2 & 340.0 & -3.7 \\
\hline $4 \mathrm{H}-1,114$ & 1.1 & 271.1 & 8.0 & $11 \mathrm{H}-5,22$ & 1.8 & 110.2 & 4.2 & $4 \mathrm{H}-1,114$ & 0.3 & 98.0 & -13.5 \\
\hline $4 \mathrm{H}-2,114$ & 1.0 & 95.7 & -13.7 & $11 \mathrm{H}-5,60$ & 1.9 & 293.2 & 14.3 & $4 \mathrm{H}-2,114$ & 0.8 & 280.8 & 9.0 \\
\hline $4 \mathrm{H}-3,8$ & 1.6 & 180.4 & -67.9 & $11 \mathrm{H}-5,114$ & 1.8 & 296.2 & 15.7 & $4 \mathrm{H}-3,114$ & 0.9 & 274.7 & 14.0 \\
\hline $4 \mathrm{H}-3,65$ & 0.7 & 263.2 & 12.1 & $11 \mathrm{H}-6,8$ & 1.7 & 277.4 & 54.3 & $4 \mathrm{H}-4,114$ & 0.5 & 273.3 & 10.7 \\
\hline $4 \mathrm{H}-4,114$ & 0.9 & 269.5 & 4.2 & $11 \mathrm{H}-6,114$ & 0.8 & 284.9 & 7.4 & $4 \mathrm{H}-5,114$ & 7.5 & 86.4 & -35.7 \\
\hline $4 \mathrm{H}-5,114$ & 1.7 & 251.8 & 0.3 & $11 \mathrm{H}-6,146$ & 1.4 & 169.0 & 6.1 & $4 \mathrm{H}-6,114$ & 0.6 & 283.9 & 13.4 \\
\hline $4 \mathrm{H}-6,114$ & 2.2 & 249.0 & 11.7 & $12 \mathrm{H}-1,40$ & 4.2 & 286.7 & -20.7 & $5 \mathrm{H}-1,118$ & 2.4 & 126.3 & -11.1 \\
\hline $6 \mathrm{H}-2,60$ & 2.1 & 77.7 & -13.6 & $12 \mathrm{H}-1,76$ & 4.4 & 283.9 & -10.1 & $5 \mathrm{H}-2,118$ & 1.2 & 320.5 & 10.4 \\
\hline $6 \mathrm{H}-3,110$ & 2.1 & 87.4 & -12.6 & $12 \mathrm{H}-1,114$ & 4.0 & 157.9 & -22.4 & $5 \mathrm{H}-3,118$ & 1.5 & 144.5 & -10.5 \\
\hline $6 \mathrm{H}-4,70$ & 3.8 & 264.1 & 24.0 & $12 \mathrm{H}-1,144$ & 6.7 & 287.6 & -37.6 & $5 \mathrm{H}-4,118$ & 0.9 & 302.1 & 20.2 \\
\hline $6 \mathrm{H}-5,47$ & 2.9 & 270.5 & 16.4 & $12 \mathrm{H}-2,20$ & 2.1 & 28.4 & 9.1 & $5 \mathrm{H}-5,118$ & 0.8 & 302.1 & 12.0 \\
\hline $6 \mathrm{H}-6,36$ & 7.4 & 258.5 & 19.3 & $12 \mathrm{H}-2,114$ & 1.7 & 28.1 & -59.2 & $5 \mathrm{H}-6,118$ & 0.7 & 285.1 & 16.2 \\
\hline $7 \mathrm{H}-2,114$ & 1.0 & 54.0 & 29.5 & $12 \mathrm{H}-3,20$ & 1.5 & 104.8 & 14.0 & $6 \mathrm{H}-1,118$ & 1.0 & 107.1 & 26.9 \\
\hline $7 \mathrm{H}-3,114$ & 2.4 & 64.9 & 18.4 & $12 \mathrm{H}-4,114$ & 1.7 & 251.4 & -32.1 & $6 \mathrm{H}-2,118$ & 1.6 & 273.5 & -8.3 \\
\hline $7 \mathrm{H}-4,114$ & 0.0 & 33.7 & 34.7 & $12 \mathrm{H}-4,148$ & 0.7 & 271.1 & -16.0 & $6 \mathrm{H}-3,118$ & 1.5 & 282.2 & 1.2 \\
\hline $7 \mathrm{H}-4,116$ & 6.6 & 208.4 & -16.4 & $12 \mathrm{H}-6,4$ & 1.5 & 248.0 & -7.3 & $6 \mathrm{H}-4,118$ & 2.0 & 274.4 & -10.9 \\
\hline $7 \mathrm{H}-5,114$ & 3.2 & 216.5 & -23.0 & $12 \mathrm{H}-6,90$ & 1.1 & 89.9 & 8.6 & $6 \mathrm{H}-5,118$ & 0.9 & 274.9 & -11.8 \\
\hline $7 \mathrm{H}-6,114$ & 2.8 & 200.4 & -8.2 & $12 \mathrm{H}-6,114$ & 1.4 & 103.8 & -0.6 & $6 \mathrm{H}-6,90$ & 1.0 & 100.4 & 15.1 \\
\hline $8 \mathrm{H}-1,40$ & 9.6 & 161.1 & 9.2 & $12 \mathrm{H}-7,2$ & 1.3 & 94.5 & 46.6 & $7 \mathrm{H}-1,120$ & 4.7 & 35.3 & 10.1 \\
\hline $8 \mathrm{H}-1,114$ & 5.7 & 354.9 & 19.3 & $12 \mathrm{H}-7,66$ & 3.4 & 255.9 & -36.8 & $7 \mathrm{H}-2,120$ & 1.5 & 202.5 & -13.3 \\
\hline $8 \mathrm{H}-1,40$ & 9.6 & 161.1 & 9.2 & $13 \mathrm{H}-1,114$ & 1.5 & 285.8 & -11.5 & $7 \mathrm{H}-3,120$ & 0.6 & 209.1 & -7.1 \\
\hline $8 \mathrm{H}-2,114$ & 0.8 & 6.3 & 18.0 & $13 \mathrm{H}-2,114$ & 2.8 & 282.1 & -22.0 & $7 \mathrm{H}-4,120$ & 1.1 & 26.6 & 21.1 \\
\hline $8 \mathrm{H}-3,114$ & 0.6 & 171.3 & -13.3 & $13 \mathrm{H}-3,114$ & 0.5 & 105.3 & 12.7 & $7 \mathrm{H}-6,120$ & 1.3 & 212.5 & -19.7 \\
\hline $8 \mathrm{H}-5,114$ & 0.8 & 191.3 & -15.4 & $13 \mathrm{H}-4,100$ & 3.9 & 265.0 & -21.7 & $9 \mathrm{H}-2,118$ & 2.0 & 24.0 & -8.7 \\
\hline $8 \mathrm{H}-6,114$ & 1.4 & 188.5 & -25.6 & $13 \mathrm{H}-4,114$ & 2.0 & 270.9 & -15.1 & $9 \mathrm{H}-2,118$ & 5.6 & 24.8 & -0.3 \\
\hline $9 \mathrm{H}-1,114$ & 0.8 & 94.3 & -13.1 & $13 \mathrm{H}-4,122$ & 2.1 & 265.5 & -4.7 & $9 \mathrm{H}-3,88$ & 3.2 & 39.5 & -9.4 \\
\hline $9 \mathrm{H}-2,141$ & 0.9 & 109.7 & -5.3 & $13 \mathrm{H}-4,142$ & 3.1 & 265.3 & -7.9 & $9 \mathrm{H}-3,104$ & 1.9 & 46.0 & -15.9 \\
\hline $9 \mathrm{H}-3,114$ & 1.6 & 111.8 & -21.7 & $13 \mathrm{H}-5,76$ & 5.4 & 118.1 & 32.2 & $9 \mathrm{H}-3,115$ & 3.2 & 36.9 & -17.7 \\
\hline $9 \mathrm{H}-4,114$ & 1.6 & 111.8 & -21.7 & $13 \mathrm{H}-5,90$ & 1.4 & 105.9 & 27.8 & $9 \mathrm{H}-3,130$ & 4.7 & 42.2 & -13.3 \\
\hline $9 \mathrm{H}-5,114$ & 1.3 & 99.5 & -54.2 & $13 \mathrm{H}-5,114$ & 1.8 & 97.4 & 7.5 & $9 \mathrm{H}-4,70$ & 1.3 & 220.9 & 14.8 \\
\hline $9 \mathrm{H}-6,83$ & 4.6 & 297.2 & 28.6 & $13 \mathrm{H}-5,122$ & 0.8 & 113.7 & 26.9 & $9 \mathrm{H}-4,88$ & 1.1 & 228.7 & 8.9 \\
\hline $9 \mathrm{H}-6,114$ & 4.0 & 270.0 & 14.9 & $13 \mathrm{H}-5,142$ & 2.1 & 109.6 & 26.1 & $9 \mathrm{H}-4,104$ & 0.5 & 227.9 & 16.0 \\
\hline $9 \mathrm{H}-7,52$ & 0.7 & 78.9 & 30.2 & $13 \mathrm{H}-6,100$ & 1.0 & 101.0 & 18.0 & $9 \mathrm{H}-4,118$ & 0.7 & 229.4 & 18.1 \\
\hline $10 \mathrm{H}-1,114$ & 2.9 & 231.8 & -46.7 & $13 \mathrm{H}-6,114$ & 2.5 & 103.2 & 8.8 & $9 \mathrm{H}-5,20$ & 3.6 & 36.3 & -14.5 \\
\hline $10 \mathrm{H}-1,146$ & 2.1 & 210.3 & -37.6 & $13 \mathrm{H}-6,122$ & 1.8 & 110.7 & 27.6 & $9 \mathrm{H}-5,30$ & 3.0 & 36.7 & -5.6 \\
\hline $10 \mathrm{H}-2,88$ & 2.2 & 345.5 & 0.2 & $13 \mathrm{H}-6,142$ & 4.2 & 117.7 & 23.4 & $9 \mathrm{H}-5,118$ & 2.3 & 47.6 & -7.8 \\
\hline $10 \mathrm{H}-2,114$ & 1.7 & 193.7 & -49.2 & & & & & $9 \mathrm{H}-6,118$ & 3.6 & 73.6 & -30.3 \\
\hline
\end{tabular}

general, the paleomagnetic results from this site are satisfactory. As with measurements from other sites, PTM inclinations are typically quite scattered because of core barrel effects, but declination shifts usually appear to record reversals reliably. We judged that polarity sense on the basis of inclinations from discrete sample measurements (Table 8), which were less disturbed by core barrel effects, or from what appeared to be well-behaved intervals in the PTM record.

In most sections, the magnetostratigraphy derived from these APC cores (Fig. 13 and Table 9) can be reasonably correlated to the GPTS. This is true for the Pleistocene, Pliocene, and upper Miocene intervals, as well as for the upper Oligocene. The correlat in for the highly dissolved middle and lower Miocene intervals is, however, more problematic. The paleomagnetic results from Cores $115-711 \mathrm{~A}-5 \mathrm{H},-6 \mathrm{H},-7 \mathrm{H}$, and $-8 \mathrm{H}$ all proved uninterpretable. These same levels did, however, yield reasonable results in Hole 711B, except for the few meters recovered in
Core $115-711 \mathrm{~B}-7 \mathrm{H}$ that gave only scattered directions. The uppermost $40 \mathrm{~m}$ of sediment provide a polarity reversal pattern that can be readily matched to the GPTS by assuming that this portion of the section contains no major hiatuses. This proposition appears to be confirmed by the nannofossil stratigraphy (Backman, Duncan, et al., 1988, pp. 664-669): the Pliocene/ Pleistocene boundary is located at about 9 mbsf (Hole 711A), consistent with our placement of the Olduvai Subchron; the Pliocene/Miocene boundary is at $21 \mathrm{msbf}$ (Hole 711A) in a reversely magnetized interval that we associate with the lowermost Gilbert. Furthermore, the nannofossil stratigraphy places the $\mathrm{CN} 9 \mathrm{a} / \mathrm{CN} 9 \mathrm{~b}$ zonal boundary in Core $115-711 \mathrm{~A}-4 \mathrm{H}$, confirming our interpretation that this core contains the bottom of Chron $\mathrm{C} 3 \mathrm{~A}$ and the top of Chron $\mathrm{C} 4$.

The interpretation given for the highly condensed interval spanned by Core 115-711B-6H is not nearly so well constrained. The polarity sense can only be tentatively chosen in this core be- 




$115-710 \mathrm{~A}-6 \mathrm{H}-3,110-112 \mathrm{~cm}$



$115-710 \mathrm{~A}-13 \mathrm{H}-3,114-116 \mathrm{~cm}$

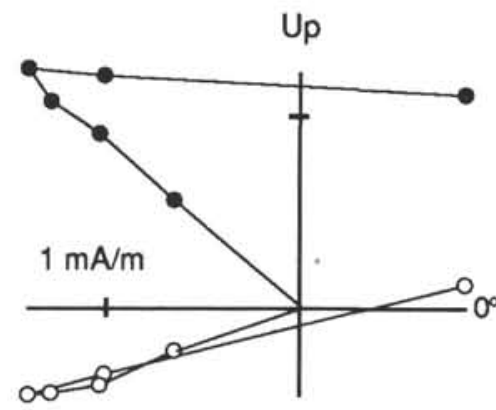

$115-710 \mathrm{~B}-9 \mathrm{H}-4,70-72 \mathrm{~cm}$

$115-710 \mathrm{~B}-5 \mathrm{H}-3,118-120 \mathrm{~cm}$

Figure 12. Orthogonal demagnetization diagrams for samples from remagnetization-free intervals from Site 710. Open dots show projections on vertical plane, closed dots show projection on horizontal plane. Demagnetization is by alternating fields with intensity as high as $60 \mathrm{mT}$.

Table 7. Average inclination from remagnetizationfree intervals in Site 710.

\begin{tabular}{lrrrrr}
\hline \multicolumn{1}{c}{ Core } & $N$ & $\mathrm{I}_{\text {(ave) }}$ & $\mathrm{I}_{(\mathrm{mle})}$ & \multicolumn{1}{c}{$\kappa$} & ${ }{ }_{95}$ \\
\hline $115-710 \mathrm{~B}-5 \mathrm{H}$ & 6 & $-13.4^{\circ}$ & $-13.4^{\circ}$ & 208.6 & $4.3^{\circ}$ \\
$115-710 \mathrm{~A}-6 \mathrm{H}$ & 10 & $-15.9^{\circ}$ & $-16.0^{\circ}$ & 155.2 & $3.7^{\circ}$ \\
$115-710 \mathrm{~B}-9 \mathrm{H}$ & 15 & $-14.7^{\circ}$ & $-14.9^{\circ}$ & 35.3 & $6.3^{\circ}$ \\
$115-710 \mathrm{~A}-13 \mathrm{H}$ & 16 & $-18.4^{\circ}$ & $-18.6^{\circ}$ & 43.1 & $5.5^{\circ}$ \\
\hline
\end{tabular}

Note: $N=$ number of samples; $\mathrm{I}_{(\text {ave })}=$ arithmetic average inclination; $I_{(m l e)}=$ maximum likelihood estimate of inclination; and $\kappa=$ maximum likelihood estimate of the Fisher precision parameter. $\alpha_{95}$ is estimated from $N$ and $\kappa$.

cause the discrete sample inclinations were inconsistent, and the opposite assignment is entirely possible. This difficulty also exists for Core 115-711B-8H. Moreover, the sediment interval spanned by these cores is largely barren of fossils, adding to the difficulty.

The correlation of magnetozones identified in Cores $9 \mathrm{H}$, $10 \mathrm{H}$, and $11 \mathrm{H}$ of both Site 711 holes is based on the identification of the LO of S. ciperoensis (top of CP19) near the top of Core 115-711A-9H (Backman, Duncan, et al., 1988, pp. 664$669)$, which is thought to correspond to a time just after Chron C7 (Berggren et al., 1985b). Thus, we associate the normal zone in Core 115-711A-9H that occurs below this biostratigraphic datum level with Chron C7. This assignment also appears to be consistent with the presence of a relatively thick, reversely mag- netized zone just above this level (identified in Hole 711B) that we correlate with $\mathrm{C} 6 \mathrm{CR}$. Because all of the Oligocene sediments recovered before APC refusal can be assigned to nannofossil Zone CP19, we can reasonably assume that no significant hiatus is present and that the two normal polarity zones found in Cores 115-711A-10H and -11H (and in Core 115-711B-11H) can be correlated with Chrons $\mathrm{C} 8$ and $\mathrm{C} 9$.

Following the procedures described for Site 710, we have estimated inclination averages only for the cores that showed minimal overprinting and have averaged only the inclination values determined from progressive AF demagnetization of discrete samples. The cores used were $115-711 \mathrm{~A}-11 \mathrm{H}, 115-711 \mathrm{~B}-4 \mathrm{H}$, $115-711 \mathrm{~B}-10 \mathrm{H}$, and $115-711 \mathrm{~B}-11 \mathrm{H}$. The resulting inclination averages for each of these cores are given in Table 10 .

\section{Sites 712 and 713}

Sites 712 and 713 are located $3 \mathrm{~km}$ apart on the northern Chagos Bank at about $2900 \mathrm{~m}$ water depth. The priority of basement objectives at Sites 712 and 713 dictated that the sediment cover be rotary cored. Consequently, the Eocene- to Pleistocene-age sediments recovered at these sites were highly disturbed by drilling and are not amenable to paleomagnetic study. A few samples, however, were analyzed in an effort to obtain an inclination estimate. These samples of the basal Eocene chalk gave erratic results (Backman, Duncan, et al., 1988, pp. 746748 ), and no conclusions concerning the paleolatitude could be drawn. 
Table 8. Progressive AF demagnetization results from discrete samples sed in constructing magnetostratigraphy of Site 711 .

\begin{tabular}{|c|c|c|c|c|c|c|c|c|c|c|c|}
\hline $\begin{array}{l}\text { Core, section, } \\
\text { interval }(\mathrm{cm})\end{array}$ & MAD & $\begin{array}{l}\text { Declination } \\
\text { (degrees) }\end{array}$ & $\begin{array}{l}\text { Inclination } \\
\text { (degrees) }\end{array}$ & $\begin{array}{l}\text { Core, section, } \\
\text { interval }(\mathrm{cm})\end{array}$ & MAD & $\begin{array}{l}\text { Declination } \\
\text { (degrees) }\end{array}$ & $\begin{array}{l}\text { Inclination } \\
\text { (degrees) }\end{array}$ & $\begin{array}{l}\text { Core, section, } \\
\text { interval }(\mathrm{cm})\end{array}$ & MAD & $\begin{array}{l}\text { Declination } \\
\text { (degrees) }\end{array}$ & $\begin{array}{c}\text { Inclination } \\
\text { (degrees) }\end{array}$ \\
\hline $115-711 \mathrm{~A}-$ & & & & 115-711A- (Cont & & & & 115-711B- (Con & & & \\
\hline $1 \mathrm{H}-1,116$ & 1.8 & 100.0 & -31.6 & $11 \mathrm{H}-2,114$ & 2.6 & 305.1 & 24.1 & $5 \mathrm{H}-5,114$ & 3.0 & 326.9 & -19.4 \\
\hline $1 \mathrm{H}-2,116$ & 1.7 & 107.2 & -24.1 & $11 \mathrm{H}-2,140$ & 1.5 & 298.7 & 12.8 & $5 \mathrm{H}-6,114$ & 5.8 & 336.8 & -30.6 \\
\hline $1 \mathrm{H}-3,116$ & 0.8 & 92.4 & -17.4 & $11 \mathrm{H}-3,10$ & 2.3 & 307.4 & 16.2 & $6 \mathrm{H}-1,114$ & 1.1 & 271.7 & 2.1 \\
\hline $1 \mathrm{H}-4,116$ & 1.1 & 87.3 & -16.2 & $11 \mathrm{H}-3,32$ & 1.9 & 309.5 & 14.7 & $6 \mathrm{H}-3,114$ & 8.9 & 94.4 & 4.6 \\
\hline $1 \mathrm{H}-5,116$ & 1.0 & 263.8 & -0.6 & $11 \mathrm{H}-3,60$ & 1.5 & 309.8 & 25.7 & $6 \mathrm{H}-4,114$ & 13.0 & 88.4 & -16.3 \\
\hline $2 \mathrm{H}-1,114$ & 1.3 & 169.3 & 5.9 & $11 \mathrm{H}-3,114$ & 1.6 & 137.0 & -22.3 & $6 \mathrm{H}-5,126$ & 5.6 & 246.1 & 24.4 \\
\hline $2 \mathrm{H}-2,114$ & 2.5 & 348.5 & 43.8 & $11 \mathrm{H}-3,140$ & 1.4 & 136.8 & -17.4 & $6 \mathrm{H}-6,126$ & 3.0 & 208.2 & 46.5 \\
\hline $2 \mathrm{H}-3,114$ & 1.0 & 81.8 & 0.0 & $11 \mathrm{H}-4,10$ & 1.2 & 125.1 & -15.3 & $7 \mathrm{H}-1,114$ & 1.7 & 154.8 & -11.3 \\
\hline $3 \mathrm{H}-1,114$ & 2.8 & 127.0 & -17.5 & $11 \mathrm{H}-4,32$ & 4.1 & 117.0 & -20.0 & $7 \mathrm{H}-2,114$ & 1.7 & 61.0 & -7.5 \\
\hline $3 \mathrm{H}-2,114$ & 1.4 & 307.4 & 11.9 & $11 \mathrm{H}-4,60$ & 1.7 & 126.6 & -11.6 & $7 \mathrm{H}-3,114$ & 10.8 & 282.0 & -1.9 \\
\hline $3 \mathrm{H}-3,114$ & 0.8 & 296.7 & 12.1 & $11 \mathrm{H}-4,84$ & 0.6 & 126.1 & -11.6 & $8 \mathrm{H}-1,114$ & 8.6 & 153.0 & -7.6 \\
\hline $3 \mathrm{H}-4,114$ & 0.9 & 297.2 & 3.8 & $11 \mathrm{H}-4,114$ & 3.2 & 130.0 & -10.6 & $8 \mathrm{H}-2,114$ & 12.7 & 337.1 & -1.6 \\
\hline $3 \mathrm{H}-5,114$ & 1.6 & 104.8 & -21.6 & $11 \mathrm{H}-4,126$ & 2.4 & 122.9 & -20.4 & $8 \mathrm{H}-3,114$ & 7.2 & 171.0 & 11.5 \\
\hline $3 \mathrm{H}-6,114$ & 2.9 & 262.1 & 3.5 & $11 \mathrm{H}-4,140$ & 2.4 & 125.6 & -13.6 & $8 \mathrm{H}-4,114$ & 2.0 & 193.6 & 2.0 \\
\hline $4 \mathrm{H}-2,114$ & 2.1 & 229.9 & 7.4 & $11 \mathrm{H}-5,114$ & 1.5 & 135.1 & -20.1 & $8 \mathrm{H}-5,114$ & 10.8 & 197.8 & -28.1 \\
\hline $4 \mathrm{H}-3,114$ & 2.4 & 218.7 & 33.2 & $11 \mathrm{H}-6,114$ & 3.0 & 116.9 & -22.8 & $8 \mathrm{H}-6,114$ & 8.0 & 318.1 & 28.9 \\
\hline $4 \mathrm{H}-4,114$ & 1.3 & 200.0 & -4.2 & & & & & $9 \mathrm{H}-1,55$ & 4.5 & 48.0 & 11.2 \\
\hline $4 \mathrm{H}-5,114$ & 2.2 & 25.2 & -11.0 & 115-711B- & & & & $9 \mathrm{H}-2,55$ & 2.1 & 50.8 & 26.0 \\
\hline $4 \mathrm{H}-6,114$ & 0.7 & 25.7 & -20.0 & & & & & $9 \mathrm{H}-3,55$ & 3.6 & 51.4 & 10.4 \\
\hline $5 \mathrm{H}-1,114$ & 1.5 & 251.1 & 18.0 & $1 \mathrm{H}-1,120$ & .8 & 57.2 & -14.4 & $9 \mathrm{H}-5,55$ & 6.7 & 61.5 & -25.1 \\
\hline $5 \mathrm{H}-2,114$ & 1.1 & 84.9 & 28.5 & $2 \mathrm{H}-1,114$ & 1.8 & 330.3 & -0.8 & $9 \mathrm{H}-6,55$ & 2.7 & 143.6 & -62.9 \\
\hline $5 \mathrm{H}-3,114$ & 0.9 & 89.7 & 10.2 & $2 \mathrm{H}-2,114$ & 1.4 & 177.9 & -7.0 & $10 \mathrm{H}-1,114$ & 1.5 & 332.4 & 20.5 \\
\hline $5 \mathrm{H}-4,114$ & 6.9 & 65.0 & -3.6 & $2 \mathrm{H}-3,114$ & .9 & 354.2 & 7.2 & $10 \mathrm{H}-2,10$ & 3.6 & 77.6 & 33.5 \\
\hline $5 \mathrm{H}-5,114$ & 2.6 & 220.7 & 13.2 & $2 \mathrm{H}-4,114$ & 1.0 & 18.3 & 4.5 & $10 \mathrm{H}-2,34$ & 3.3 & 255.0 & -29.1 \\
\hline $5 \mathrm{H}-6,114$ & 3.1 & 191.1 & 6.4 & $2 \mathrm{H}-5,114$ & 1.0 & 183.2 & -16.4 & $10 \mathrm{H}-2,66$ & .7 & 81.1 & 11.6 \\
\hline $6 \mathrm{H}-1,114$ & 2.6 & 204.6 & -29.3 & $2 \mathrm{H}-6,114$ & 1.2 & 351.0 & 22.6 & $10 \mathrm{H}-2,82$ & 2.2 & 76.5 & 17.4 \\
\hline $6 \mathrm{H}-2,114$ & 2.0 & 192.0 & -42.4 & $3 \mathrm{H}-1,114$ & 1.0 & 58.4 & -10.8 & $10 \mathrm{H}-2,98$ & 2.4 & 81.6 & 19.1 \\
\hline $7 \mathrm{H}-1,114$ & 5.3 & 224.0 & -0.3 & $3 \mathrm{H}-2,114$ & .8 & 26.0 & -8.7 & $10 \mathrm{H}-2,124$ & 2.1 & 76.2 & 18.7 \\
\hline $7 \mathrm{H}-2,114$ & 3.7 & 286.8 & 10.4 & $3 \mathrm{H}-3,114$ & 1.7 & 210.8 & 1.2 & $10 \mathrm{H}-2,145$ & 7.8 & 269.8 & -10.8 \\
\hline $7 \mathrm{H}-3,114$ & 3.4 & 333.2 & -31.8 & $3 \mathrm{H}-4,114$ & 2.0 & 199.4 & -2.1 & $10 \mathrm{H}-3,10$ & 4.1 & 233.2 & -14.7 \\
\hline $7 \mathrm{H}-4,114$ & 2.7 & 315.8 & 1.3 & $3 \mathrm{H}-5,114$ & 3.1 & 0.1 & -40.1 & $10 \mathrm{H}-3,24$ & 2.2 & 247.4 & -8.9 \\
\hline $7 \mathrm{H}-5,114$ & 3.2 & 136.6 & 26.1 & $4 \mathrm{H}-1,114$ & 5.1 & 121.9 & -32.1 & $10 \mathrm{H}-3,38$ & 2.1 & 250.8 & -16.9 \\
\hline $7 \mathrm{H}-6,114$ & 0.6 & 323.3 & 14.2 & $4 \mathrm{H}-2,114$ & 1.3 & 122.6 & -15.8 & $10 \mathrm{H}-3,114$ & 3.6 & 77.4 & 28.2 \\
\hline $8 \mathrm{H}-1,114$ & 1.6 & 176.6 & -20.5 & $4 \mathrm{H}-3,114$ & 1.2 & 106.2 & -14.4 & $10 \mathrm{H}-4,114$ & 3.4 & 85.9 & 19.5 \\
\hline $8 \mathrm{H}-2,114$ & 1.3 & 161.8 & -14.3 & $4 \mathrm{H}-4,10$ & 1.5 & 94.8 & -9.6 & $11 \mathrm{H}-1,114$ & 1.1 & 309.4 & -14.6 \\
\hline $8 \mathrm{H}-3,114$ & 2.4 & 152.4 & 4.2 & $4 \mathrm{H}-4,30$ & 1.5 & 90.6 & -3.9 & $11 \mathrm{H}-2,114$ & 5.7 & 125.9 & 11.0 \\
\hline $9 \mathrm{H}-2,114$ & 1.4 & 174.2 & 11.2 & $4 \mathrm{H}-4,50$ & 1.9 & 95.9 & -5.6 & $11 \mathrm{H}-3,114$ & 3.0 & 301.1 & -3.3 \\
\hline $9 \mathrm{H}-3,114$ & 2.3 & 185.2 & 1.2 & $4 \mathrm{H}-4,70$ & 2.8 & 93.4 & -3.6 & $11 \mathrm{H}-4,114$ & 3.3 & 111.9 & 14.8 \\
\hline $9 \mathrm{H}-4,114$ & 1.6 & 354.5 & -17.7 & $4 \mathrm{H}-4,90$ & 3.4 & 93.8 & -11.7 & $11 \mathrm{H}-5,10$ & 5.3 & 106.6 & 17.6 \\
\hline $9 \mathrm{H}-5,114$ & 1.1 & 176.5 & 3.5 & $4 \mathrm{H}-4,114$ & 4.4 & 89.5 & -25.6 & $11 \mathrm{H}-5,26$ & 2.1 & 112.5 & 14.0 \\
\hline $9 \mathrm{H}-6,114$ & 2.1 & 178.8 & 12.7 & $4 \mathrm{H}-5,10$ & 3.9 & 268.6 & 11.2 & $11 \mathrm{H}-5,40$ & 1.6 & 113.2 & 7.7 \\
\hline $10 \mathrm{H}-1,114$ & 2.3 & 39.8 & -83.8 & $4 \mathrm{H}-5,40$ & .6 & 263.0 & 25.3 & $11 \mathrm{H}-5,58$ & 3.7 & 117.8 & 21.5 \\
\hline $10 \mathrm{H}-2,114$ & 0.5 & 140.1 & -83.0 & $4 \mathrm{H}-5,70$ & 1.7 & 266.9 & 14.3 & $11 \mathrm{H}-5,74$ & 2.9 & 116.7 & 20.5 \\
\hline $10 \mathrm{H}-3,114$ & 2.7 & 6.5 & -39.4 & $4 \mathrm{H}-5,95$ & 1.1 & 256.9 & 7.5 & $11 \mathrm{H}-5,94$ & 2.6 & 113.6 & 15.9 \\
\hline $10 \mathrm{H}-4,114$ & 3.6 & 5.6 & -32.1 & $4 \mathrm{H}-5,114$ & 1.5 & 267.3 & 9.5 & $11 \mathrm{H}-5,114$ & 3.1 & 116.9 & 19.0 \\
\hline $10 \mathrm{H}-5,114$ & 1.8 & 350.2 & -25.9 & $4 \mathrm{H}-5,140$ & 0.6 & 262.4 & 20.1 & $11 \mathrm{H}-6,10$ & 5.4 & 142.0 & 49.3 \\
\hline $10 \mathrm{H}-6,114$ & 1.4 & 341.1 & -15.6 & $4 \mathrm{H}-6,114$ & 5.1 & 76.4 & 5.8 & $11 \mathrm{H}-6,26$ & 3.0 & 302.3 & -19.1 \\
\hline $11 \mathrm{H}-2,10$ & 1.0 & 334.1 & 20.8 & $5 \mathrm{H}-1,114$ & 1.2 & 351.4 & -16.2 & $11 \mathrm{H}-6,40$ & 3.6 & 292.3 & -15.9 \\
\hline $11 \mathrm{H}-2,32$ & 2.8 & 321.9 & 19.5 & $5 \mathrm{H}-2,114$ & .5 & 346.1 & -17.5 & $11 \mathrm{H}-6,114$ & 5.2 & 288.6 & -19.9 \\
\hline $11 \mathrm{H}-2,60$ & 1.0 & 307.7 & 23.6 & $5 \mathrm{H}-3,114$ & 2.4 & 187.4 & 5.2 & $11 \mathrm{H}-6,140$ & 2.9 & 118.0 & 11.0 \\
\hline $11 \mathrm{H}-2,106$ & 2.2 & 310.3 & 24.0 & $5 \mathrm{H}-4,114$ & 3.1 & 163.8 & -6.5 & & & & \\
\hline
\end{tabular}

Note: $\mathrm{MAD}=$ mean angular deviation of principal component fit to progressive AF demagnetization data. Declination is given with respect to fiducial line on core liner.

\section{Site 714}

Site 714 is situated on the eastern flank of the Maldives Ridge at a water depth of $2232 \mathrm{~m}$. The sediment column recovered at this site is composed of a Pleistocene unit overlying a unit of upper Oligocene to upper Miocene nannofossil ooze. The remanent magnetization of all but the upper few meters of Pleistocene age sediment recovered proved to be quite weak. Although the topmost $5 \mathrm{~m}$ did show reasonably strong remanence and stable magnetization directions, the remanence intensity decreases (Fig. 14) and paleomagnetic signal coherence deteriorates markedly with depth, giving essentially random directions in most of the cores. This trend with depth matches that found in magnetic susceptibility measurements (Backman, Duncan, et al., 1988, pp. 856-857) and presumably reflects the absence of any appreciable magnetic carrier through most of the section.

\section{Site 715}

Site 715 is located at $5^{\circ} 5^{\prime} \mathrm{N}, 73^{\circ} 50^{\prime} \mathrm{E}$ on the eastern side of the Maldives Ridge at a water depth of $2273 \mathrm{~m}$. Basement objectives were the primary concern at Site 715 ; therefore, rotary drilling was used to penetrate the $210 \mathrm{~m}$ of overlying sediment, composed of Neogene-age nannofossil ooze and an Eocene reef assemblage. No useful paleomagnetic measurements were obtained from sediments at this site: apart from the likely drilling disturbance from rotary coring, paleomagnetic measurement was difficult with the PTM because the Neogene-age sediments showed only weak magnetization. The recovery rate in drilling 


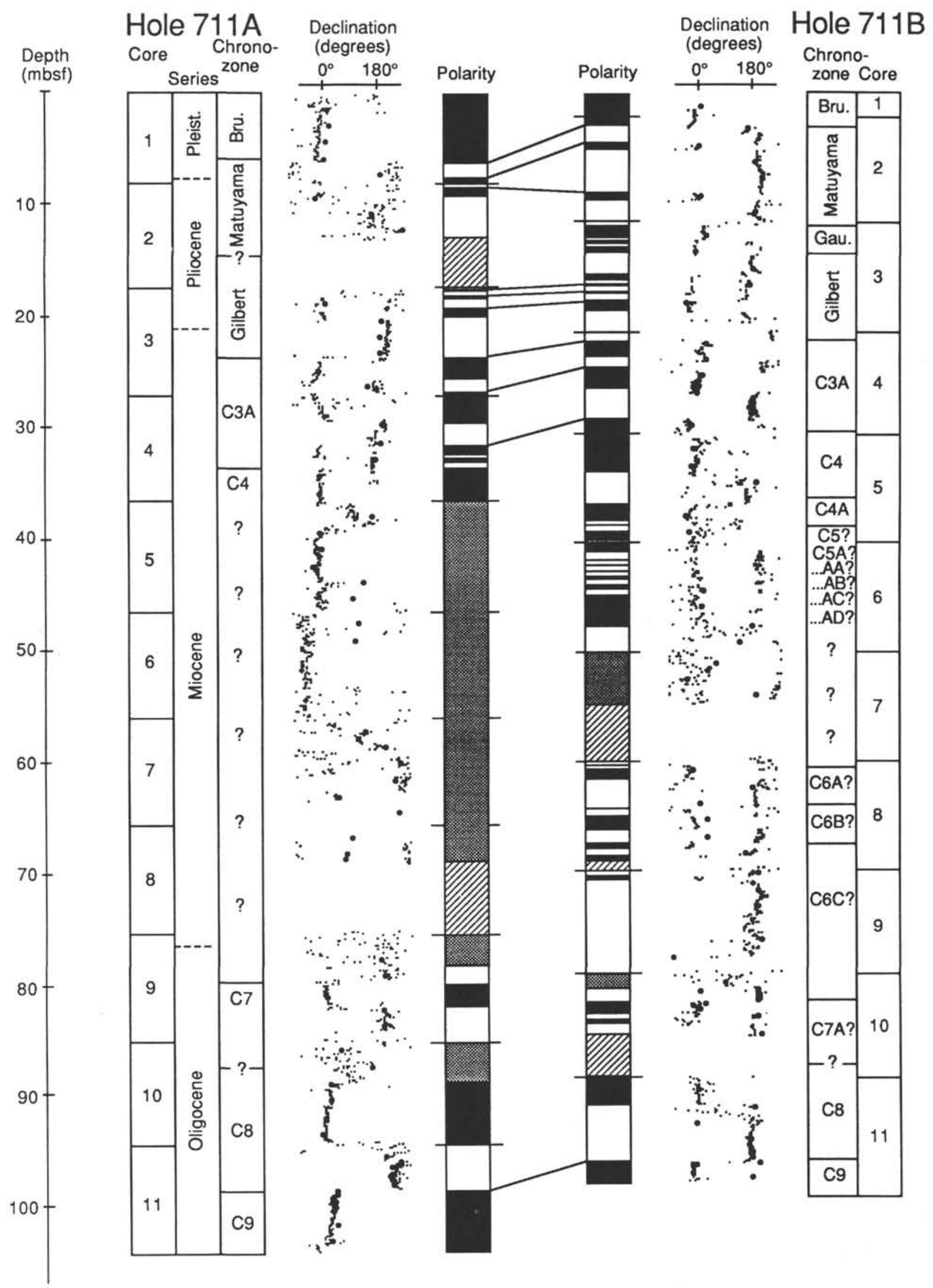

Figure 13. Magnetic polarity stratigraphy determined for Site 711. Conventions as in Figure 11. 
Table 9. Reversal boundary depths for Site 711.

\begin{tabular}{|c|c|c|c|c|}
\hline $\begin{array}{l}\text { Core, section, } \\
\text { interval }(\mathrm{cm})\end{array}$ & $\begin{array}{l}\text { Depth } \\
\text { (mbsf) }\end{array}$ & Sense & Interpretation & $\begin{array}{l}\text { Age } \\
\text { (Ma) }\end{array}$ \\
\hline
\end{tabular}

115-711A-

\begin{tabular}{|c|c|c|c|c|}
\hline IH-5, 0 & 6.0 & $\mathrm{R}-\mathrm{N}$ & Brunhes/Matuyama & 0.73 \\
\hline $1 \mathrm{H}-6,20$ & 7.7 & $\mathrm{~N}-\mathrm{R}$ & Jaramillo $(\mathrm{T})$ & 0.91 \\
\hline $3 \mathrm{H}-1,70$ & 18.4 & $\mathrm{R}-\mathrm{N}$ & Nunivak (O) & 4.24 \\
\hline $3 \mathrm{H}-1,100$ & 18.7 & $\mathrm{~N}-\mathrm{R}$ & Sidufjall (T) & 4.40 \\
\hline $3 \mathrm{H}-1,130$ & 19.0 & $\mathrm{R}-\mathrm{N}$ & Sidufjall $(\mathrm{O})$ & 4.47 \\
\hline $3 \mathrm{H}-2,20$ & 19.4 & N-R & Thvera $(\mathrm{T})$ & 4.57 \\
\hline $3 \mathrm{H}-2,110$ & 20.3 & R-N & Thvera (O) & 4.77 \\
\hline $3 \mathrm{H}-5,30$ & 24.0 & $N-R$ & C3AN1 (T) & 5.35 \\
\hline $3 \mathrm{H}-6,70$ & 25.9 & R-N & C3AN1 (O) & 5.53 \\
\hline $3 \mathrm{H}-7,23$ & 26.9 & N-R & C3AN2 (T) & 5.68 \\
\hline $4 \mathrm{H}-2,60$ & 29.4 & $\mathrm{R}-\mathrm{N}$ & C3AN2(O) & 5.89 \\
\hline $4 \mathrm{H}-3,130$ & 31.6 & N-R & C3AN3 (T) & 6.37 \\
\hline $4 \mathrm{H}-4,30$ & 32.1 & R-N & $?$ & \\
\hline $4 \mathrm{H}-4,50$ & 32.3 & N-R & ? & \\
\hline $4 \mathrm{H}-4,100$ & 32.8 & $\mathrm{R}-\mathrm{N}$ & $\mathrm{C} 3 \mathrm{AN} 3(\mathrm{O})$ & 6.50 \\
\hline $4 \mathrm{H}-5,50$ & 33.8 & $\mathrm{~N}-\mathrm{R}$ & $\mathrm{C} 4 \mathrm{~N} 1(\mathrm{~T})$ & 6.70 \\
\hline $9 \mathrm{H}-3,130$ & 79.9 & $\mathrm{~N}-\mathrm{R}$ & $\mathrm{C} \mathrm{N} 1$ (T) & 25.50 \\
\hline $9 \mathrm{H}-5,110$ & 82.7 & R-N & $\mathrm{C} 7 \mathrm{~N} 2(\mathrm{O})$ & 25.97 \\
\hline $11 \mathrm{H}-3,100$ & 98.8 & N-R & $\mathrm{C} 9 \mathrm{~N} 1 \mathrm{~T})$ & 28.15 \\
\hline
\end{tabular}

115-711B-

\begin{tabular}{|c|c|c|c|c|}
\hline $2 \mathrm{H}-1,110$ & 3.2 & $\mathrm{R}-\mathrm{N}$ & Brunhes/Matuyama & 0.73 \\
\hline $2 \mathrm{H}-2,100$ & 4.6 & $\mathrm{~N}-\mathrm{R}$ & Jaramlllo $(\mathrm{T})$ & 0.91 \\
\hline $2 \mathrm{H}-3,10$ & 5.2 & $\mathrm{R}-\mathrm{N}$ & Jaramillo $(\mathrm{O})$ & 0.98 \\
\hline $2 \mathrm{H}-5,100$ & 9.1 & $\mathrm{~N}-\mathrm{R}$ & Olduvai (T) & 1.66 \\
\hline $2 \mathrm{H}-6,10$ & 9.7 & $\mathrm{R}-\mathrm{N}$ & Olduvai(O) & 1.88 \\
\hline $3 \mathrm{H}-1,20$ & 11.9 & N-R & Matuyama/Gauss & 2.47 \\
\hline $3 \mathrm{H}-2,20$ & 13.4 & $\mathrm{R}-\mathrm{N}$ & Kaena $(\mathrm{T})$ & 2.92 \\
\hline $3 \mathrm{H}-2,50$ & 13.7 & N-R & Kaena $(\mathrm{O})$ & 2.99 \\
\hline $3 \mathrm{H}-2,140$ & 14.6 & $\mathrm{R}-\mathrm{N}$ & Gauss/Gilbert & 3.40 \\
\hline $3 \mathrm{H}-4,30$ & 16.5 & $N-R$ & Cochiti (T) & 3.88 \\
\hline $3 \mathrm{H}-4,70$ & 16.9 & $\mathrm{R}-\mathrm{N}$ & Cochiti (O) & 3.97 \\
\hline $3 \mathrm{H}-4,120$ & 17.4 & N-R & Nunivak $(\mathrm{T})$ & 4.10 \\
\hline $3 \mathrm{H}-5,0$ & 17.7 & $\mathrm{R}-\mathrm{N}$ & Nunivak (O) & 4.24 \\
\hline $3 \mathrm{H}-5,20$ & 17.9 & N-R & Sidufjall $(\mathrm{T})$ & 4.40 \\
\hline $3 \mathrm{H}-5,40$ & 18.1 & $\mathrm{R}-\mathrm{N}$ & Sidufjall (O) & 4.47 \\
\hline $3 \mathrm{H}-5,100$ & 18.7 & N-R & Thvera (T) & 4.57 \\
\hline $3 \mathrm{H}-6,60$ & 19.8 & R-N & Thvera (O) & 4.77 \\
\hline $4 \mathrm{H}-1,90$ & 22.3 & N-R & C3AN1 (T) & 5.35 \\
\hline $4 \mathrm{H}-2,120$ & 24.1 & R-N & C3AN1 $(\mathrm{O})$ & 5.53 \\
\hline $4 \mathrm{H}-3,80$ & 25.2 & N-R & C3AN2(T) & 5.68 \\
\hline
\end{tabular}

the underlying reef carbonates was poor, and most of the sediments obtained were so brecciated by drilling that the resulting small pieces were impossible to orient for paleomagnetic study.

\section{Site 716}

The sediments recovered at Site 716 , which was located at $4^{\circ} 56^{\prime} \mathrm{N}, 73^{\circ} 17^{\prime} \mathrm{E}$ between the two parallel atoll chains of the Maldives, consist of a poorly consolidated foraminifer-bearing nannofossil ooze. These sediments are dark colored, yet they show uniformly high carbonate contents (Backman, Duncan, et al., 1988, p. 1008). Our expectation was that these seemingly reduced sediments would yield only scattered directions similar to those obtained at Site 714; however, the remanence directions measured aboard ship proved to be far more stable. Cores 115$716 \mathrm{~A}-19 \mathrm{H}$ through $-27 \mathrm{H}$ were measured with the PTM. Sediment from shallower depths was too poorly consolidated to send through the magnetometer, and discrete samples from the upper portion of the section produced scattered directions when examined during shore-based study (Fig. 15). The PTM measurements of Cores $115-716 \mathrm{~A}-19 \mathrm{H}$ through $-27 \mathrm{H}$ showed consistent declinations within core and shallow inclinations that were reasonably appropriate to the site latitude. No reversals, however, were detected. Although the sediment from these eight cores gave consistent results when measured aboard ship, the consistency of the shipboard PTM results does not indicate whether a primary magnetization was preserved or whether
Table 9 (continued).

\begin{tabular}{|c|c|c|c|c|}
\hline $\begin{array}{l}\text { Core, section, } \\
\text { interval }(\mathrm{cm})\end{array}$ & $\begin{array}{l}\text { Depth } \\
\text { (mbsf) }\end{array}$ & Sense & Interpretation & $\begin{array}{l}\text { Age } \\
\text { (Ma) }\end{array}$ \\
\hline \multicolumn{5}{|c|}{ 115-711B-(Cont.) } \\
\hline $4 \mathrm{H}-4,120$ & 27.1 & R-N & C3AN2(O) & 5.89 \\
\hline $4 \mathrm{H}-6,50$ & 29.4 & $\mathrm{~N}-\mathrm{R}$ & $\mathrm{C} 3 \mathrm{AN} 3(\mathrm{~T})$ & 6.37 \\
\hline $5 \mathrm{H}-3,50$ & 34.5 & $\mathrm{R}-\mathrm{N}$ & $\mathrm{C} 4 \mathrm{~N} 3(\mathrm{~T})$ & 7.41 \\
\hline $5 \mathrm{H}-5,20$ & 37.2 & N-R & C4AN1 (T) & 7.90 \\
\hline $5 \mathrm{H}-5,140$ & 38.4 & $\mathrm{R}-\mathrm{N}$ & C4AN1 (O) & 8.21 \\
\hline $5 \mathrm{H}-6,20$ & 38.7 & $\mathrm{~N}-\mathrm{R}$ & C4AN2 (T) & 8.41 \\
\hline $5 \mathrm{H}-6,50$ & 39.0 & $\mathrm{R}-\mathrm{N}$ & C4AN2(O) & 8.50 \\
\hline $5 \mathrm{H}-6,80$ & 39.3 & N-R & C4AN3 (T)? & 8.71 \\
\hline $6 \mathrm{H}-1,60$ & 41.3 & R-N? & $\mathrm{C} 5 \mathrm{~N} 2(\mathrm{O}) ?$ & 10.59 \\
\hline $6 \mathrm{H}-1,120$ & 41.9 & $\mathrm{~N}-\mathrm{R} ?$ & C5ANI (T)? & 11.55 \\
\hline $6 \mathrm{H}-1,140$ & 42.1 & R-N? & C5ANI (O)? & 11.73 \\
\hline $6 \mathrm{H}-2,10$ & 42.3 & $\mathrm{~N}-\mathrm{R} ?$ & C5AN2 (T)? & 11.86 \\
\hline $6 \mathrm{H}-2,20$ & 42.4 & $\mathrm{R}-\mathrm{N}$ ? & C5AN2 (O)? & 12.12 \\
\hline $6 \mathrm{H}-2,80$ & 43.0 & N-R? & C5AN3 $(\mathrm{T}) ?$ & 12.46 \\
\hline $6 \mathrm{H}-2,110$ & 43.3 & $\mathrm{R}-\mathrm{N}$ ? & C5AN4 $(\mathrm{O}) ?$ & 12.62 \\
\hline $6 \mathrm{H}-2,130$ & 43.5 & $\mathrm{~N}-\mathrm{R} ?$ & CSAAN (T)? & 12.83 \\
\hline $6 \mathrm{H}-3,20$ & 43.9 & $\mathrm{R}-\mathrm{N} ?$ & CSAAN (O)? & 13.01 \\
\hline $6 \mathrm{H}-3,70$ & 44.4 & N-R? & C5ABN $(\mathrm{T}) ?$ & 13.20 \\
\hline $6 \mathrm{H}-3,120$ & 44.9 & $\mathrm{R}-\mathrm{N} ?$ & C5ABN $(\mathrm{O}) ?$ & 13.46 \\
\hline $6 \mathrm{H}-4,0$ & 45.2 & N-R? & C5ACN $(\mathrm{T}) ?$ & 13.69 \\
\hline $6 \mathrm{H}-4,140$ & 46.6 & $\mathrm{R}-\mathrm{N}$ ? & $\mathrm{C} 5 \mathrm{ACN}(\mathrm{O}) ?$ & 14.08 \\
\hline $6 \mathrm{H}-5,20$ & 46.9 & N-R? & C5ADN (T)? & 14.20 \\
\hline $6 \mathrm{H}-5,120$ & 47.9 & R-N? & C5ADN $(\mathrm{O}) ?$ & 14.66 \\
\hline $8 \mathrm{H}-1,60$ & 60.6 & $\mathrm{~N}-\mathrm{R}$ ? & $?$ & \\
\hline $8 \mathrm{H}-1,90$ & 60.9 & $\mathrm{R}-\mathrm{N}$ ? & $?$ & \\
\hline $8 \mathrm{H}-1,110$ & 61.1 & $\mathrm{~N}-\mathrm{R} ?$ & $?$ & \\
\hline $8 \mathrm{H}-2,50$ & 62.0 & $\mathrm{R}-\mathrm{N}$ ? & $?$ & \\
\hline $8 \mathrm{H}-4,10$ & 64.6 & $\mathrm{~N}-\mathrm{R} ?$ & C6BN (T)? & 22.57 \\
\hline $8 \mathrm{H}-4,50$ & 65.0 & R-N? & $?$ & \\
\hline $8 \mathrm{H}-4,80$ & 65.3 & $\mathrm{~N}-\mathrm{R}$ ? & $?$ & \\
\hline $8 \mathrm{H}-5,40$ & 66.4 & $\mathrm{R}-\mathrm{N}$ ? & C6BN $(\mathrm{O}) ?$ & 22.97 \\
\hline $8 \mathrm{H}-6,20$ & 67.7 & $\mathrm{~N}-\mathrm{R} ?$ & $\mathrm{C} 6 \mathrm{CN} 1$ (T)? & 23.27 \\
\hline $8 \mathrm{H}-6,80$ & 68.3 & R-N? & $\mathrm{C} 6 \mathrm{CN} 1(\mathrm{O}) ?$ & 23.44 \\
\hline $8 \mathrm{H}-6,130$ & 68.8 & N-R? & $\mathrm{C} 6 \mathrm{CN} 2(\mathrm{~T}) ?$ & 23.55 \\
\hline $9 \mathrm{H}-1,90$ & 70.8 & $\mathrm{~N}-\mathrm{R}$ & $\mathrm{C} 6 \mathrm{CN} 3(\mathrm{~T})$ & 24.04 \\
\hline $9 \mathrm{H}-1,120$ & 71.1 & $\mathrm{R}-\mathrm{N}$ & $\mathrm{C} 6 \mathrm{CN} 3(\mathrm{O})$ & 24.21 \\
\hline $10 \mathrm{H}-2,130$ & 82.1 & N-R & C7AN (T) & 26.38 \\
\hline $10 \mathrm{H}-3,100$ & 83.3 & $\mathrm{R}-\mathrm{N}$ & C7AN (O) & 26.56 \\
\hline $11 \mathrm{H}-2,100$ & 91.4 & $\mathrm{~N}-\mathrm{R}$ & $\mathrm{C} 8 \mathrm{~N} 2(\mathrm{O})$ & 27.74 \\
\hline $11 \mathrm{H}-6,20$ & 96.6 & R-N & C9N1 (T) & 28.15 \\
\hline
\end{tabular}

Note: $\mathrm{O}=$ onset and $\mathrm{T}=$ termination.

Table 10. Average inclination from remagnetizationfree intervals in Site 711.

\begin{tabular}{cccccc}
\hline Core & $N$ & $\mathrm{I}_{(\text {ave) }}$ & $\mathrm{I}_{\text {(mle) }}$ & \multicolumn{1}{c}{$\kappa$} & $\alpha_{95}$ \\
\hline $115-711 \mathrm{~B}-4 \mathrm{H}$ & 16 & $-13.5^{\circ}$ & $-13.6^{\circ}$ & 46.2 & $5.3^{\circ}$ \\
$115-711 \mathrm{~B}-10 \mathrm{H}$ & 13 & $-19.1^{\circ}$ & $-19.3^{\circ}$ & 60.9 & $5.2^{\circ}$ \\
$115-711 \mathrm{~A}-11 \mathrm{H}$ & 21 & $-18.4^{\circ}$ & $-18.4^{\circ}$ & 152.1 & $2.5^{\circ}$ \\
$115-711 \mathrm{~B}-11 \mathrm{H}$ & 15 & $-15.1^{\circ}$ & $-15.1^{\circ}$ & 127.5 & $3.3^{\circ}$ \\
\hline
\end{tabular}

Note: $N=$ number of samples; $\mathbf{l}_{(\text {ave) }}=$ arithmetic average inclination; $\mathrm{I}_{(\mathrm{mle})}=$ maximum likelihood estimate of inclination; and $k=$ maximum likelihood estimate of the Fisher precision parameter. $\alpha_{95}$ is estimated from $N$ and $\kappa$.

these sediments only recorded a present-day viscous overprint. Biostratigraphic analysis (Backman, Duncan, et al., 1988, pp. $1008-1011$ ) of Cores $115-716 \mathrm{~A}-19 \mathrm{H}$ to $-27 \mathrm{H}$ indicates a high sedimentation rate for shipboard measurements of this interval (perhaps as high as $50-60 \mathrm{~m} / \mathrm{m}$.y.) and so the lack of reversals in the PTM measurements does not necessarily rule out the possibility that a primary magnetization was recorded. Inclination measurements on Cores 115-716A-19H to $-27 \mathrm{H}$ (Fig. 15, top) are, on average, directed downward at a shallow angle $\left(10.3^{\circ}\right)$ and would seem most consistent with the direction of a normal polarity dipole field $\left(9 \cdot 8^{\circ}\right)$. However, the longest interval of uni- 


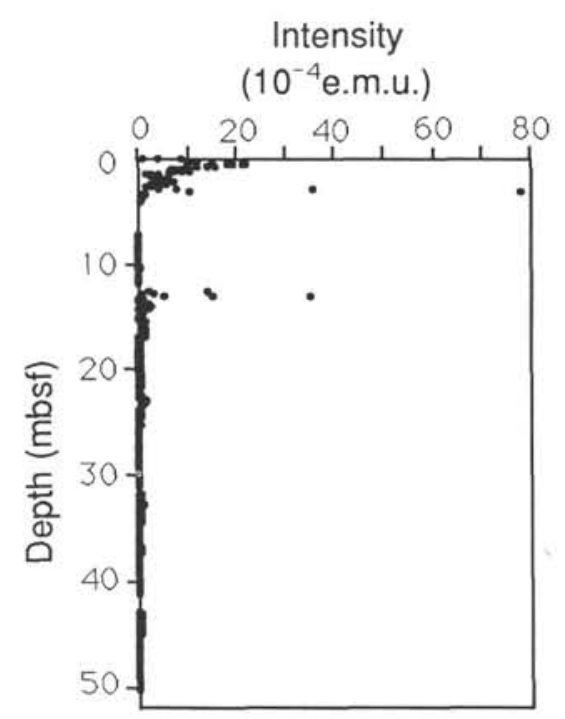

Figure 14. Intensity of magnetization (total moment) measured after 5$\mathrm{mT}$ demagnetization in archive half cores from the upper portion of the section recovered at Site 714 . form polarity within the age range indicated by the biostratigraphic results is of reversed polarity (lower Gilbert Chron). The present-day field inclination at this site is $-7.9^{\circ}$ and thus does not match the observed inclinations. It may well be that the stable remanence results from a longer term viscous or, possibly, postdepositional remanent magnetization along the expected dipole field.

\section{DISCUSSION}

Implications of the magnetostratigraphy determined from Leg 115 sediments to problems in Neogene biostratigraphic calibration are discussed elsewhere (Backman et al., this volume). In this discussion, we focus on the paleolatitude results deduced from Leg 115 sediments by comparing the paleolatitude determined from Sites 706,710 , and 711 with predicted paleolatitudes (Table 11). These predictions were determined by calculating the ancient positions of these sites according to the absolute plate motion model of Duncan (1981), which is based on fixed (African) hotspots.

In general, agreement between the paleomagnetic estimates and the hotspot predictions is reasonably good; however, our estimates of dipole paleolatitude are typically somewhat steeper than would be predicted from the fixed hotspot model (Fig. 16). This steepening is found in seven of the nine estimates; however, the discrepancy does fall within estimated errors in three of these cases. It is, of course, possible for the results from any one hole to be systematically in error if the hole did not penetrate the sediments vertically. Indeed, drift measurements ob-

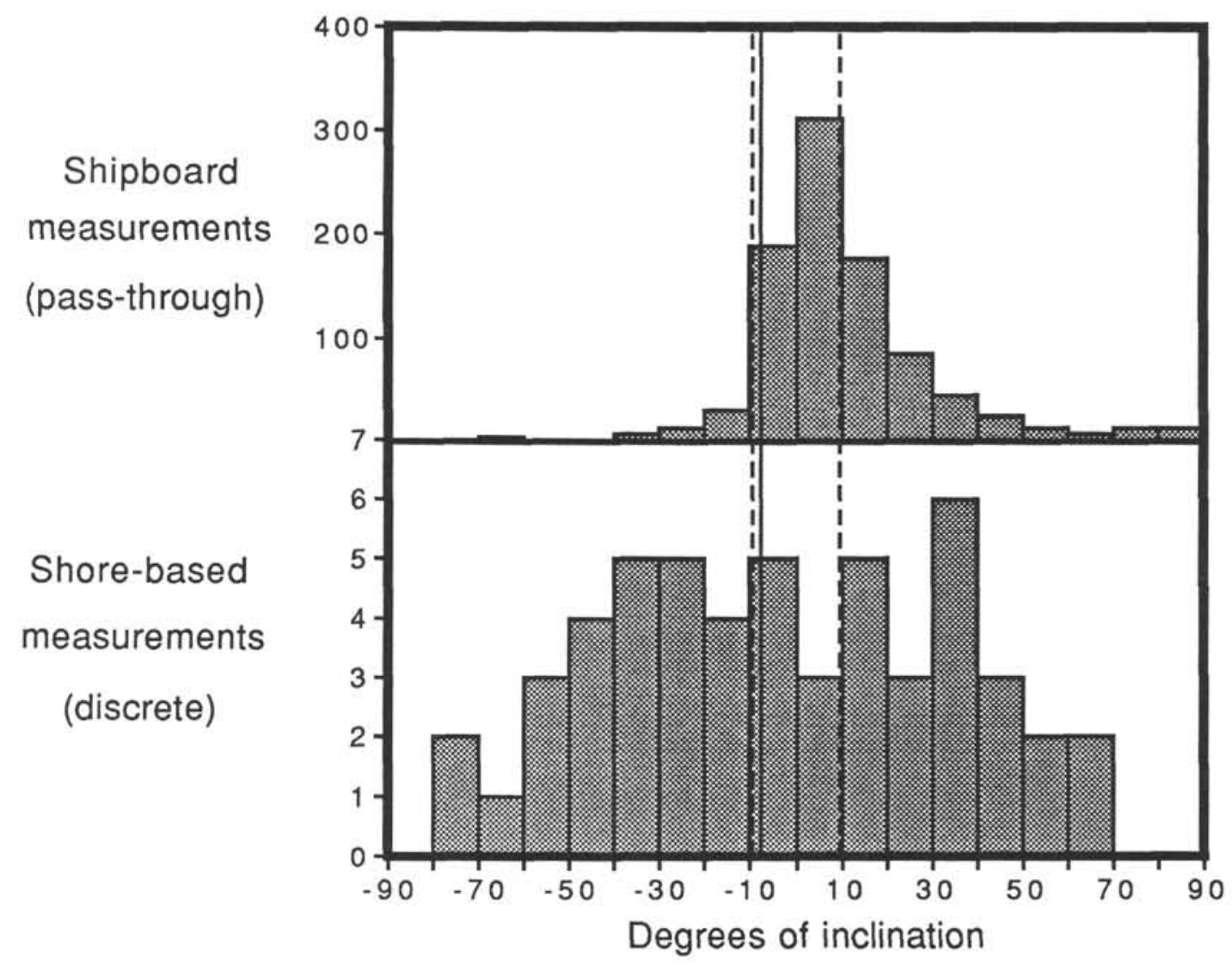

Figure 15. Histogram of inclination measurements on sediments from Site 716. Top panel shows inclination results from PTM measurement of Cores 115-716A-19H through -27H; bottom panel shows inclination measured in discrete samples (after 10-mT demagnetization) taken from Cores 115-716B-1H through $-10 \mathrm{H}$. Dashed vertical lines indicate dipole field inclination (positive for normal polarity, negative for reverse); solid vertical line shows present-day field inclination at the site. 
Table 11. Comparison of estimated paleolatitudes from Leg 115 sediments with predictions of a fixed hotspot plate motion model.

\begin{tabular}{ccccc}
\hline $\begin{array}{c}\text { Age } \\
(\mathrm{Ma})\end{array}$ & $\begin{array}{c}\text { Hole } \\
\text { and } \\
\text { core }\end{array}$ & $\begin{array}{c}\text { Dipole } \\
\text { paleolatitude } \\
\text { (min, max) }\end{array}$ & $\begin{array}{c}\text { Dipole }+ \text { Quadrupole } \\
\text { paleolatitude } \\
\text { (min, max) }\end{array}$ & $\begin{array}{c}\text { Hotspot } \\
\text { paleolatitude }\end{array}$ \\
\hline 5 & $710 \mathrm{~B}-5 \mathrm{H}$ & $-6.8^{\circ}(-5.0,-8.6)$ & $-5.1^{\circ}(-3.4,-6.9)$ & $-4.8^{\circ}$ \\
6 & $710 \mathrm{~A}-6 \mathrm{H}$ & $-8.2^{\circ}(-6.6,-9.7)$ & $-6.5^{\circ}(-4.9,-8.1)$ & $-4.9^{\circ}$ \\
6 & $711 \mathrm{~B}-4 \mathrm{H}$ & $-6.9^{\circ}(-4.7,-9.1)$ & $-5.2^{\circ}(-3.1,-7.5)$ & $-3.4^{\circ}$ \\
9 & $710 \mathrm{~B}-9 \mathrm{H}$ & $-7.6^{\circ}(-5.0,-10.3)$ & $-5.9^{\circ}(-3.4,-8.6)$ & $-5.2^{\circ}$ \\
22 & $710 \mathrm{~A}-13 \mathrm{H}$ & $-9.6^{\circ}(-7.2,-12.0)$ & $-7.9(-5.5,-10.3)$ & $-6.8^{\circ}$ \\
26 & $711 \mathrm{~B}-10 \mathrm{H}$ & $-9.9^{\circ}(-7.7,-12.2)$ & $-8.2^{\circ}(-6.0,-10.6)$ & $-6.5^{\circ}$ \\
28 & $711 \mathrm{~A}-11 \mathrm{H}$ & $-9.4^{\circ}(-8.4,-10.5)$ & $-7.8^{\circ}(-6.7,-8.8)$ & $-7.2^{\circ}$ \\
28 & $711 \mathrm{~B}-11 \mathrm{H}$ & $-7.7^{\circ}(-6.3,-9.1)$ & $-6.0^{\circ}(-4.7,-7.4)$ & $-7.2^{\circ}$ \\
33 & 706 (all) & $-20.2^{\circ}(-17.5,-23.0)$ & $-18.4^{\circ}(-15.7,-21.3)$ & $-19.4^{\circ}$ \\
\hline
\end{tabular}

Note: Paleolatitude is estimated from observed inclination, using the dipole formula or with $3.8 \%$ contribution from the axial quadrupole; minimum and maximum limits are based on $0.8 \times \alpha_{95}$ estimate (see text). Hotspot paleolatitude is predicted using rotation parameters of Duncan (1981).



Figure 16. Comparison of observed and predicted paleolatitudes from Site 706 (square), Site 710 (closed circles), and Site 711 (open circles). Predicted paleolatitudes for the sites (solid lines) are calculated by interpolation from the African plate rotation parameters of Duncan (1981). Dashed line shows the presumed paleolatitude of the Réunion hotspot, assuming it has been fixed throughout the interval. Observed paleolatitudes are calculated from the mean inclination of selected remagnetization-free intervals, assuming a geocentric axial dipole (upper panel) or a geocentric axial dipole $+3.8 \%$ axial quadrupole field (lower panel) (Table 11).

tained from the orientation tool (Table 1) do show deviations from vertical of about $2^{\circ}$ for Hole $710 \mathrm{~A}$ and about $4^{\circ}$ for Hole $711 \mathrm{~A}$. In the worst case, these deviations might lead to paleolatitude errors of $1^{\circ}-2^{\circ}$; however, the orientation tool indicates that the drift was directed largely west (for Hole 710A) or east (for Hole 711A) and thus should have minimal effect on the measured inclination. We must, however, be aware that drift of a given hole may introduce errors of $1^{\circ}-2^{\circ}$ into the estimates of paleolatitude from those cores where hole drift was not measured. (This might, for example, account for the $1.7^{\circ}$ difference in paleolatitude determined for 28 -Ma sediments in the two different holes at Site 711.) It seems difficult, however, to attribute the consistent steepening of inclination in the four separate holes $(710 \mathrm{~A}, 710 \mathrm{~B}, 711 \mathrm{~A}$, and $711 \mathrm{~B})$ to a random deviation from vertical.

Three possible systematic error sources need to be considered: compaction of the sediments, drift of the hotspots, and long-term nondipole fields. Compaction-induced shallowing of inclination has been shown to occur at $\sim 100-200 \mathrm{~m}$ depth in several deep-sea sediment sections from the North Atlantic (Celaya and Clement, 1988), and this effect is most severe at midlatitude sites. Thus, it is possible, for instance, that compaction of the sediments from Site 706 has shallowed the paleomagnetic inclination by a few degrees. Although the section recovered at Site 706 is only about $40 \mathrm{~m}$ thick, the seismic surveys indicate that, adjacent to the canyon where Site 706 is located, the typical sediment thickness is about $300 \mathrm{~m}$. This setting, as well as the lack of any observed gradient in bulk density or water content (Backman, Duncan, et al., 1988, pp. 149-151), suggests that these sediments were buried more deeply at one time.

A second systematic error may stem from the slow drift of the African hotspots. Because the paleolatitude determined by paleomagnetic data from the Deccan Traps is some $8^{\circ} \mathrm{S}$ of Réunion Island (Klootwijk, 1979; Courtillot et al., 1986), it is thought possible that the hotspot has been moving slowly northward since its beginning. The paleomagnetic results from Leg 115 sediments, however, do not show an increasing discrepancy with age, as might be expected if the hotspots are drifting northward uniformly. An alternative explanation for the generally steep inclinations (compared to the hotspot predictions) is that there may have been a contribution from long-term nondipole fields. Estimates of the long-term nondipole fields have been made for the Cenozoic and Mesozoic (Coupland and Van der Voo, 1980; Livermore et al., 1983, 1984); however, the exact configuration of the nondipole field is not well known throughout these intervals. The magnitude of the nondipole field is, however, well documented for the Pliocene-Pleistocene (Merrill and McElhinny, 1977; Livermore et al., 1983), particularly at equatorial latitudes (Schneider and Kent, 1988). If we assume that a similar nondipole field existed earlier in the Neogene, we can formulate paleolatitude estimates that take this effect into account. Doing so (Fig. 16) shows that a $3.8 \%$ quadrupole field (i.e., one similar to the average equatorial field of the PliocenePleistocene) renders paleolatitudes from Leg 115 sediments that are in good agreement with those calculated by assuming that the African hotspots have remained fixed since $33 \mathrm{Ma}$.

\section{CONCLUSION}

Although sediments from many of the sites did not provide readily interpretable paleomagnetic data, those from Sites 706, 709,710 , and 711 gave important results. Sediments from Site 
706 indicated no reversals within the recovered section, but nevertheless appear to show a reliable reversed polarity primary direction based on a positive between-hole fold test. The magnetic polarity stratigraphy derived from Site 709 sediments is limited but can be reasonably interpreted in two sedimentary sections of Pliocene-Pleistocene and Oligocene-Miocene age. Sediments recovered at Sites 710 and 711 render a magnetic polarity stratigraphy that adds significantly to the body of data available to address problems in Miocene geochronology.

In addition to these magnetostratigraphic results, the paleomagnetism of these sediments can be used to determine paleolatitude. Although we cannot exclude the possibility of slight compaction effects, limited hotspot motion, or unpredicted nondipole field components affecting the paleolatitude estimates, all these effects would appear to be minor. Indeed, the paleomagnetic results obtained from Leg 115 sediments are in agreement with the least complicated hypothesis: that during the past $33 \mathrm{~m} . \mathrm{y}$. , the time-averaged geomagnetic field has maintained the same configuration as the recent field (including a few percent zonal nondipole contribution), while at the same time the (African) hotspots have remained fixed.

\section{REFERENCES}

Backman, J., Duncan, R. A., et al., 1989. Proc ODP, Init. Repts., 115: College Station, TX (Ocean Drilling Program).

Backman, J., and Shackleton, N. J., 1983. Quantitative biochronology of Pliocene and early Pleistocene calcareous nannofossils from the Atlantic, Pacific, and Indian oceans. Mar. Micropaleontol., 8:141170.

Berggren, W. A., Kent, D. V., and Flynn, J. J., 1985a. Jurassic to Paleogene: Part 2. Paleogene geochronology and chronostratigraphy. In Snelling, N. J. (Ed.), The Chronology of the Geological Record. Mem. Geol. Soc. (London), 10:141-195.

Berggren, W. A., Kent, D. V., and Van Couvering, J. A., 1985b. The Neogene: Part 2. Neogene geochronology and chronostratigraphy. In Snelling, N. J. (Ed.), The Chronology of the Geological Record. Mem. Geol. Soc. (London), 10:211-260.

Ceyala, M. A., and Clement, B. M., 1988. Inclination shallowing in deep sea sediments from the North Atlantic. Geophys. Res. Lett., 15:52-55.

Coupland, D. H., and Van der Voo, R., 1980. Long-term nondipole components in the geomagnetic field during the last 130 m.y. J. Geophys. Res., 85:3529-3548.
Courtillot, V., Besse, J., Vandamme, D., Montigny, R., Jaeger, J.-J., and Capetta, H., 1986. Deccan flood basalts at the Cretaceous/Tertiary boundary? Earth Planet. Sci. Lett., 80:361-374.

Demarest, H. H., 1983. Error analysis for the determination of tectonic rotation from paleomagnetic data. J. Geophys. Res., 88:4321-4328.

Duncan, R. A., 1981. Hotspots in the southern oceans-an absolute frame of reference for motion of the Gondwana continents. Tectonophysics, 74:29-42.

Fisher, R. A., 1953. Dispersion on a sphere. Proc. R. Soc. London, Ser. A., 217:295-305.

Kirschvink, J. L., 1980. The least-squares line and plane analysis of palaeomagnetic data. Geophys. J. R. Astron. Soc., 62:699-718.

Klootwijk, C. T., 1979. A review of palaeomagnetic data from the IndoPakistani fragment of Gondwanaland. In Farah, A., and DeJong, K. A. (Eds.), Geodynamics of Pakistan: Quetta (Geological Survey of Pakistan), 41-80.

LaBrecque, J. L., Hsü, K. J., Carman, M. F., Jr., Karpoff, A.-M., McKenzie, J. A., Percival, S. F., Jr., Petersen, N. P., Pisciotto, K. A., Schreiber, E., Tauxe, L., Tucker, P., Weissert, H. J., and Wright, R., 1983. DSDP Leg 73: contributions to Paleogene stratigraphy in nomenclature, chronology and sedimentation rates. Palaeoceanogr., Palaeoclimatol., Palaeoecol., 42:91-125.

Livermore, R. A., Vine, F. J., and Smith, A. G., 1983. Plate motions and the geomagnetic field. I. Quaternary and late Tertiary. Geophys. J. R. Astron. Soc., 73:153-171.

1984. Plate motions and the geomagnetic field. II. Jurassic to Tertiary. Geophys. J. R. Astron. Soc., 79:939-961.

McFadden, P. L., and Reid, A. B., 1982. Analysis of paleomagnetic inclination data. Geophys. J. R. Astron. Soc., 69:307-319.

Merrill, R. T., and McElhinny, M. W., 1977. Anomalies in the time-averaged paleomagnetic field and their implications for the lower mantle. Rev. Geophys., 15:309-323.

Miller, K. G., Aubry, M.-P., Khan, M. J., Melillo, A. J., Kent, D. V., and Berggren, W. A., 1985. Oligocene-Miocene biostratigraphy, magnetostratigraphy, and isotopic stratigraphy of the western North Atlantic. Geology, 13:257-261

Schneider, D. A., and Kent, D. V., 1988. The paleomagnetic field from deep-sea sediments: axial symmetry and polarity asymmetry. Science, 242:252-256.

Date of initial receipt: 31 January 1989

Date of acceptance: 26 October 1989

Ms 115B-197 